\title{
Does Elite Capture Matter? Local Elites and Targeted Welfare Programs In Indonesia Faculty Research Working Paper Series
}

\author{
Vivi Alatas
}

World Bank

Abhijit Banerjee

MIT

Rema Hanna

Harvard Kennedy School

Benjamin A. Olken

MIT

\section{Ririn Purnamasari}

World Bank

\section{Matthew Wai-Poi}

World Bank

\section{April 2013 \\ RWP13-08}

Visit the HKS Faculty Research Working Paper series at:

http://web.hks. harvard.edu/publications

The views expressed in the HKS Faculty Research Working Paper Series are those of the author(s) and do not necessarily reflect those of the John F. Kennedy School of Government or of Harvard University. Faculty Research Working Papers have not undergone formal review and approval. Such papers are included in this series to elicit feedback and to encourage debate on important public policy challenges. Copyright belongs to the author(s). Papers may be downloaded for personal use only. 


\section{Does Elite Capture Matter? \\ Local Elites and Targeted Welfare Programs in Indonesia}

Rema Hanna, Vivi Alatas, Abhijit Banerjee, Benjamin

A. Olken, Ririn Purnamasari, and Matthew Wai-Poi

CID Working Paper No. 255

January 2013

(C) Copyright 2013 Hanna, Rema; Alatas, Vivi; Banerjee, Abhijit; Olken, Benjamin A.; Purnamasari, Ririn; Wai-Poi, Matthew; and the President and Fellows of Harvard College

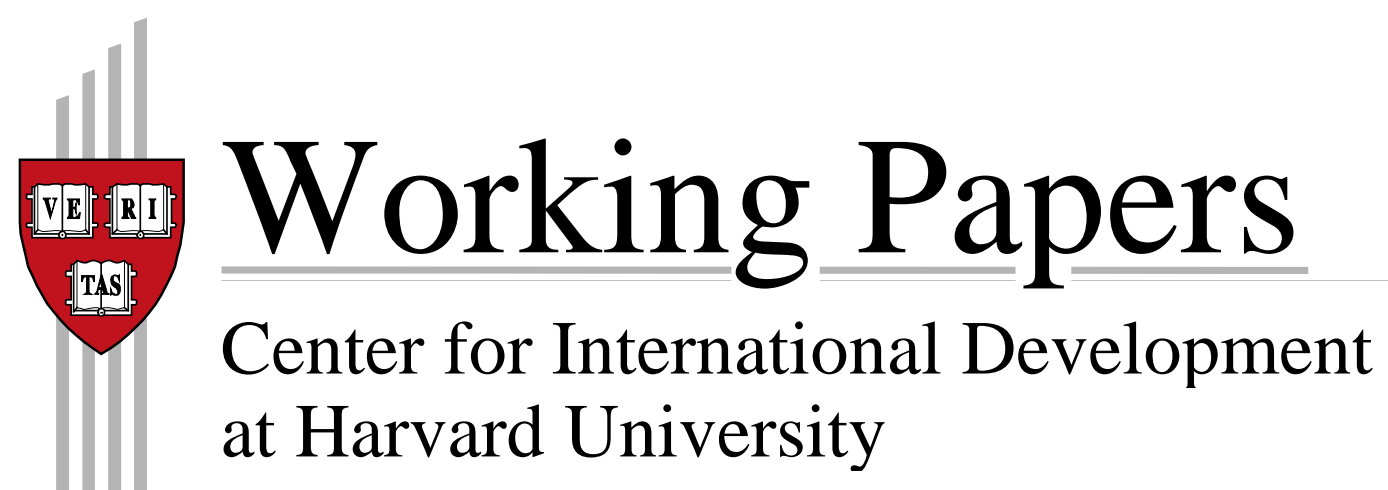




\title{
Does Elite Capture Matter? \\ Local Elites and Targeted Welfare Programs in Indonesia
}

\author{
Vivi Alatas, World Bank \\ Abhijit Banerjee, MIT \\ Rema Hanna, Harvard University \\ Benjamin A. Olken, MIT \\ Ririn Purnamasari, World Bank \\ Matthew Wai-Poi, World Bank \\ January 2013 \\ PRELIMINARY AND INCOMPLETE
}

\begin{abstract}
This paper investigates the impact of elite capture on the allocation of targeted government welfare programs in Indonesia, using both a high-stakes field experiment that varied the extent of elite influence and non-experimental data on a variety of existing government transfer programs. Conditional on their consumption level, there is little evidence that village elites and their relatives are more likely to receive aid programs than non-elites. Looking more closely, however, we find that this overall result masks a difference between different types of elites: those holding formal leadership positions are more likely to receive benefits, while informal leaders are actually less likely to. We show that capture by formal elites occurs during the distribution of benefits under the programs, and not during the processes when the beneficiary lists are determined by the central government. However, while elite capture exists, the welfare losses it creates appear quite small: since formal elites and their relatives are only 9 percent richer than non-elites, are at most about 8 percentage points more likely to receive benefits than non-elites, and represent at most 15 percent of the population, eliminating elite capture entirely would improve the welfare gains from these programs by less than one percent.
\end{abstract}

This project was a collaboration involving many people. We thank Talitha Chairunissa, Amri Ilmma, Chaeruddin Kodir, He Yang and Gabriel Zucker for their excellent research assistance, and Scott Guggenheim for helpful comments. We thank Mitra Samya, the Indonesian Central Bureau of Statistics, the National Team for the Acceleration of Poverty Reduction (TNP2K), and SurveyMeter for their cooperation implementing the project. Most of all, we thank Jurist Tan for her truly exceptional work leading the field implementation. This project was financially supported by AusAID through a World Bank trust fund, by 3ie (OW3.1055), and by the NIH (P01 HD061315). All views expressed are those of the authors, and do not necessarily reflect the views of the World Bank, TNP2K, Mitra Samya, Depsos, or the Indonesian Central Bureau of Statistics. 


\section{INTRODUCTION}

A central issue in the social sciences is the extent to which communities need outside help to achieve their goals, and a key factor in this discussion is whether the community leadership can be more or less relied upon to act in the collective interest. In particular, there is an old and influential point of view going back at least to the Federalist papers (Hamilton et al. (1787); in the development context, see also Wade, 1982 and Dreze and Sen, 1989) that local leaders are constantly scheming to extract as many resources as possible for their private use from the collective pot. In recent years, this view has been given rigorous articulation in the work of Acemoglu and Robinson (e.g., Acemoglu, 2006, Acemoglu, Reed, and Robinsion 2012).

This of course has major consequences for the design of development policy. Bardhan and Mookherjee (2005) provide a useful framework for studying the relevant trade-offs. In their model, local governments have the potential to run anti-poverty programs more effectively because of better information and potential for monitoring, but the programs may be more subject to capture by elites when they are run by local governments. ${ }^{1}$ The World Bank's 2004 World Development Report on Making Services Work for Poor People (World Bank 2004) starts from a framework very similar to that in Bardhan and Mookherjee (see chapter 3 and especially chapter 4), and consequently gives a central role to the prevention of capture in the design of social programs.

Consistent with this idea, large swaths of development policy are designed to systematically marginalize local leaders, with potentially significant costs. For example, local communities (and their leaders) do indeed often have better information about who is poor than central governments (Alderman, 2002; Galasso and Ravallion, 2005; Alatas et al 2012), but central governments are often reluctant to devolve the decision making about beneficiaries of

\footnotetext{
${ }^{1}$ In an earlier paper, Bardhan and Mookherjee (2000) they sketch a model of why this might be the case..
} 
targeted programs to local leaders, preferring to allocate benefits based on less precise, but less discretionary proxy-means test systems (Coady, Grosh, and Hoddinott, 2004). Likewise, local elites may have the skills required for construction and maintenance of infrastructure (Khwaja forthcoming), but "community driven development" programs, sponsored by the World Bank and others in more than 40 countries, are often designed to circumvent existing local elites and instead devolve decision making and implementation of projects to ordinary villagers. As a result of these policies, local elites also often have useful skills that do not get used, and there may be more long-term effects because the incentive of local leaders to acquire skill and demonstrate performance is reduced. Since local leaders often grow to become national leaders, limiting the role for local leaders can potentially lead in the long run to negative impacts on the supply of skilled national politicians as well (see, e.g., Myerson 2009).

In this paper, we set out to test, using both a high-stakes field experiment and crosssectional data on existing government programs in Indonesia, the degree to which local leaders capture targeted transfer programs, and to estimate whether the extent of this capture is quantitatively large enough to matter. Indonesia is in many ways an ideal place to study this issue both because it has a reputation for being corrupt (in 2011 it ranked 100 out of 182 countries on Transparency International's Corruption Perception Index) and because it has a long tradition of government programs that are mediated to varying extent through the village leadership.

The key to this study is an unusually detailed dataset on who is "elite" that we collected in 400 Indonesian villages: within a randomly selected sample of survey respondents, we asked each respondent to list all households in his or her neighborhood that occupy leadership positions, encompassing both formal positions (i.e. village heads, heads of hamlets, etc,) and informal 
leadership roles (i.e. respected members of the community whose influence and power is derived from social acceptance). We then asked each respondent to identify all of the formal and informal leaders' extended family members - parents, children, uncles, aunts, cousins, etc. Because some of those named households - or family members of those named households were also in our random sample of survey respondents, we can identify the relationship between being an elite household and the propensity to receive various types of government benefits. We can also compare the consumption levels of those who were named by others as elites to the rest of the population.

Using these data, we explore elite capture in three ways. First, we look at actual receipt by households of several of Indonesia's largest targeted government transfer programs: the direct cash assistance program (BLT), which distributed about US \$100 per household as one-time grants to poor households in 2005 and again in 2008; the Jamkesmas program, which provides health insurance for the poor; and the Raskin program, which provides the poor with subsidized rice. Second, we examine administrative data from the Government of Indonesia on the 2008 official asset-based targeting list (PPLS), which is the data that was collected for use in subsequent targeted programs, such as the 2011 expansion of the PKH program. This allows us to differentiate between capture when programs are actually implemented and capture through manipulation of the process by which central government enumerators survey household assets to create a targeting list.

One potential criticism of examining elite capture in these existing programs is that what we observe is the what we observe are equilibrium outcomes of program designs that already take account of the possibility of elite capture, and are designed accordingly. The actual implementation of the programs we consider, described in more detail below, does suggest that 
most program designs do allow plenty of scope for elite capture, but the possibility that we are missing something important cannot be entirely ruled out.

To deal with this concern, we ran a high-stakes field experiment where we deliberately avoided taking special steps to avoid elite capture, and then experimentally manipulated just the extent of control given to the elites. Specifically, we randomly varied the rules through which the government conducted the beneficiary selection for the 2011 expansion of Program Keluarga Harapan (PKH), Indonesia's conditional cash transfer program, in 400 new villages. PKH is perhaps the most valuable of the Government's social assistance programs: annual benefits for a household enrolled in the program average about US $\$ 150$ per year, and once enrolled, most households receive benefits for six years.

The basic design of our experiment starts from the potential beneficiary list generated by the last poverty survey implemented by the Central Statistics Bureau (BPS), which collected asset data from those households identified by village officials as potentially poor, and then used a formula based on assets and other household characteristics to determine beneficiaries. This procedure, which is called a proxy-means test, is standard operating procedure for many transfer programs in Indonesia (and many other countries), as detailed below. In randomly selected villages, we modified this system in two ways: a community-meeting approach, in which community members could modify the results of the poverty survey-based list in open, hamletlevel meetings; and an elite-meeting approach, in which only local leaders were invited to the meetings to modify the survey results in a meeting held essentially behind closed doors. In both cases, the stated reason for allowing the modification was making the lists more reliable, and it was made clear that the decision of the meeting would be final. There is no reason to think that 
the design of the base proxy-means test approach should have anticipated in any way either of these variants.

Overall, we do not find elite capture by local leaders. Looking at existing government programs, we find no clear pattern that elites or their relatives were more likely to receive assistance, conditional on their consumption level. Even more strikingly, elites are no more likely to receive benefits than non-elites in all of our experimental treatments - even when elites decide on beneficiaries behind closed doors, and even when the stakes are high $-\$ 150$ per year for up to 6 years per beneficiary. In fact, the distribution of characteristics among those targeted in the community and elite-only meetings are remarkably similar, suggesting that the local leaders were also no more likely to conduct other forms of patronage in the elite-only meetings. Note that our experimental findings in this very high stakes setting are consistent with earlier findings in a low stakes (one time transfer of US\$3) environment (Alatas et al, 2012). This suggests that these findings are quite general, holding even when the stakes increase by a factor of 300 .

When we inspect the data more closely, however, we do find some evidence of elite capture, but only for formal elites, and only in certain cases. We still find no evidence of capture by either formal or informal elites in any of the targeting mechanisms used in our experiment or in the official 2008 targeting survey conducted by the national government. However, we find that the formal leaders and their relatives are actually more likely to actually receive targeted benefits during program implementation in the 2005 and 2008 temporary cash assistance programs and the health insurance program - by as much as 8 percentage points (19 percent) more than non-elites at comparable consumption levels. In contrast, informal leaders and their 
relatives are less likely to receive targeted benefits across almost all the programs we consider than what one would expect based on their consumption levels.

The difference between the original targeting lists drawn up by the government - which show no capture - and the final allocations of programs suggests that, when it happens, elite capture occurs during the final tweaking of beneficiary lists in program implementation. Interestingly, we find formal elite capture in programs that are targeted at roughly 40 percent of the population, but we do not observe it in $\mathrm{PKH}$, which is targeted at the bottom 5 percent. Furthermore, we find that capture by formal elites is most likely to occur in villages that, for a variety of reasons we discuss later, received a larger share of benefits relative to its poverty rate. Both of these findings suggest that capture by formal elites is most likely when there are additional benefits left over after addressing the very poor, or when the coverage is high enough that it is at least plausible that relatively well-off households could potentially be eligible.

Many have argued that democracy may be an important constraint on elite capture (e.g., Foster and Rosenzweig, 2004; Faguet 2004, Bardhan and Mookherjee 2005, Martinez-Bravo et al 2011). To examine this, we take advantage of the fact that villages in urban areas generally have appointed village heads, whereas villages in rural areas generally have elected ones. This status is slow to respond to demographic shifts, so that there are both types of heads in both types of areas (Martinez-Bravo, 2012). We find that leaders do not appear to be constrained by elections: if anything, we find that the elite capture we observe for formal elites is more likely to occur in areas where the village leadership is elected.

Despite the fact that formal elites appear more likely to receive government benefits in some types of programs, the main takeaway of our paper is that quantitatively, the type of elite capture we study in this paper may not matter very much - and certainly matters much less than 
other targeting failures which are well within the government's ability to correct. Because we have detailed consumption survey data on the elites as well as non-elites, we can not only estimate whether elites receive more benefits than they should be entitled to, but we can also estimate how much richer they are than everyone else. These factors turn out to matter a lot: even though formal elites are as much as 19 percent more likely to receive certain types of benefits than they should be based on consumption, they comprise a small share of the population (15 percent) and they are not that much richer than non-elites (about 9 percent richer). Estimating the gain in social welfare from these programs formally using a CRRA utility framework, we estimate that eliminating elite capture entirely would improve the welfare gains from these programs by less than one percent.

In contrast, we show that better implementing the proxy-means test in the field could improve the welfare gains from the programs by as much as 26 to 31 percent - more than 25 times the welfare gains from eliminating elite capture. In sum, the findings suggest that focusing on improving methods to more accurately predict consumption for targeting purposes and ensuring that they are implemented in the field, rather than worrying incessantly about eliminating capture by local leaders, has a greater potential to improve delivery of these programs to the poor.

To date, the literature on elite capture in transfer programs is fairly mixed. ${ }^{2}$ What differentiates this study from the literature is that we can not only test whether elite capture exists - and we show that it does in certain cases - but we show that it does not quantitatively matter

2 For example, in India, Bardhan and Mookerjee (2006) find little elite capture in the allocation of targeted credit and agricultural kits. In contrast, Besley, Pande and Rao (2007) find that elected officials are more likely to be beneficiaries of India's transfer program. Also in India, Niehaus, Atanassova, Bertrand, and Mullainathan (forthcoming) find substantial inclusion error (70 percent) in the allocation of below poverty line cards, and nontrivial bribes, but do not document elite capture per se. In nine Ethiopian villages, Cayers and Dercon (2011) find that political connections matter in a targeted free food program during a drought, but that networks are insignificant afterwards. They find that social or political connections do not matter in terms of participation in a food-for-work program, but that those who are politically connected are rewarded in terms of cash/food receipts per day worked. 
very much for welfare. Whether elite capture is higher or lower than the upper bound of 19 percent that we find here will naturally depend on the setting, but the general principle that elites are few and far between, and not that much richer than everyone else, seems more likely to be general. While there are of course other ways that elites could capture transfer programs - for example, they could simply steal the money and not deliver the transfers at all (e.g. Olken 2006) - the costs to society from manipulating beneficiary lists seem likely to be much smaller than those deriving from other problems in generating the beneficiary lists in the first place.

The paper proceeds as follows. We discuss the empirical design and data in Section II, and then present our findings in Section III. In Section IV, we empirically benchmark the effect of elite capture on social welfare. Section V concludes.

\section{BACKGROUND, DATA, AND EXPERIMENTAL DESIGN}

\section{II.A. Background}

Corruption is generally perceived as pervasive in Indonesia. For example, in 2011 Indonesia ranked 100 out of 182 countries on Transparency International's Corruption Perception Index. When asked how corruption changed over the last three years in the Global Corruption Barometer, 43 percent of their sample stated that it had worsened. Given this environment, we would expect ex ante that elite capture may be a non-trivial concern.

Each year, the Indonesian government runs a number of household-targeted social assistance programs, with a total annual cost (as of 2009) of over USD 2.7 billion. ${ }^{3}$ The programs are similar in design to the types of targeted programs observed in many developing countries. The largest program is Raskin, a subsidized rice program, which alone typically

\footnotetext{
${ }^{3}$ This figure does not include the Direct Cash Assistance (BLT) programs, which was run in 2005 and 2008 to mitigate the effect of price shocks. The BLT was the most expensive household-targeted program in those years.
} 
accounts for about half of the household-targeted social protection budget. The government also runs a health insurance program called Jamkesmas (previously Askeskin), which was introduced in 2005 to provide basic healthcare and hospital inpatient care for 60 million people and expanded to 76 million people in 2008. In 2005 and 2008, the government additionally implemented a temporary, unconditional cash transfer program, the Direct Cash Assistance Program (Bantuan Langsung Tunai, or BLT), to mitigate the effects of price shocks. The BLT program provided about US $\$ 10$ a month to about 19.2 million poor households for a period of one year in 2005 and for nine months in 2008.

More recently, the Indonesian government has introduced a conditional cash transfer program, Program Keluarga Harapan or $\mathrm{PKH}$, which currently serves about 1.1 million households. ${ }^{4} \mathrm{PKH}$ provides assistance to families where there is a pregnant woman, there are children below the age of five, or there are children below the age of 18 that have not finished nine years of compulsory education. Program beneficiaries receive direct cash assistance ranging from Rp 600.000 to Rp 2.2 million (US\$ 67-US\$ 250) per year - or about 5-19 percent of the average yearly consumption of very poor households in our sample — for six years, conditional on family composition, school attendance, pre/postnatal check-ups, and completed vaccinations.

Targeting methodologies to select beneficiaries are often comprised of both a data-driven component and a local input component, and in the latter, village elites typically have an important role to play. For both BLT and PKH, targeting was conducted through a combination of local level inputs and proxy means testing: The Central Statistics Bureau (BPS) enumerators met with neighborhood leaders to create a list of households who could potentially qualify for the program, and the enumerators then conducted an asset survey for the listed households (this

\footnotetext{
${ }^{4}$ Program PKH Bidik 1,12 Juta Rumah Tangga Miskin. Kementrian Koordinator Bidang Kesejahteraan Rakyat. October 22, 2010. Retrieved from <http://www.menkokesra.go.id/content/program-pkh-bidik-112-juta-rumahtangga-miskin-0>, last accessed October 3, 2011.
} 
survey was called the Social Economic Registration (PSE) in 2005 and the Data Collection for Social Protection Programs (PPLS) subsequently). A proxy-means test was then used to determine eligibility using these data. For Raskin, village-level quotas were first determined by BPS, and then village level meetings are supposed to be held to finalize the list of the beneficiaries. In reality, the meetings (when held, which in fact they often are not) are just attended by local village leaders or other authorities. ${ }^{5}$ Similarly, for Jamkesmas, a district level quota was determined from the PSE/PPLS data, and then participants to fill the quota were meant to be determined from PSE/PPLS or from a list of the poor complied by the National Family Planning Board (Sparrow, Suryahadi, and Widyanti, 2010). In reality, individuals were also able to join the beneficiary list through other means, such as if they had a health card from a previous health scheme (JPS) or village-level poverty letter (SKTM) (Arifianto et al., 2005; Ministry of Health, 2005). Moreover, local officials often used their own discretion in distributing the cards.

\section{II.B. Sample Selection and Data}

The data for this project were collected to test the relative efficacy of different targeting methods in the 2011 expansion of the PKH program. As such, a sample of 400 villages was chosen from the 2,500 villages where the program was expanded in that year. ${ }^{6}$ These villages were spread across three provinces (Lampung, South Sumatera, and Central Java), in order to represent the diversity of regions within Indonesia and allow us to stratify our sample to consist of approximately 30 percent urban and 70 percent rural locations. Within each village, we randomly

\footnotetext{
${ }^{5}$ For example, in West Sumatra, the district governments often put pressure on local governments to use the BPS list with community verification, while in East Java, you often see equal sharing of the rice across the community to avoid community tensions (World Bank, 2011).

${ }^{6}$ We also randomly assigned an additional 200 villages to a "self targeting treatment," (see Alatas et al, 2012b).
} 
selected one hamlet for our surveys. These hamlets are best thought of as neighborhoods, with each having an elected or appointed administrative hamlet head.

We collected several datasets for this study. First, we conducted a baseline survey that was administered in December 2010 to March 2011 by SurveyMeter, an independent survey firm. This was completed before the government conducted targeting in PKH and, at this point, there was no mention of the experiment or of any new programs. We first randomly selected one hamlet in each village, and conducted a complete census of households, which included survey questions designed to understand whether the households would meet PKH's demographic requirements. We then randomly sampled nine households from those households who met the demographic eligibility requirement, as well as the hamlet head, for a total of 3,998 households across the 400 villages. From this sample, we collected data on consumption, a perceived ranking of the income distribution for the other households we sampled, and the full set of asset and demographic measures that comprise the predicted consumption score of the PMT.

To identify elite households, we asked respondents to list all formal and informal leaders in the hamlet. Formal leaders include members of the village government (village head, village secretary, member of village legislative council, or member of village head's staff), and hamlet heads. Informal leaders (tokoh masyarakat, or respected people) included leaders who did not hold formal positions, such as teachers and religious leaders. We then asked the respondents to identify any household in the hamlet that was related by blood or marriage to these leaders. We classify a household as being a leader if it was independently mentioned by at least two different respondents in the baseline survey, and as being "elite" if it is either a leader itself or if at least two survey respondents identify it as a leader's extended family member. 
This method of classifying elites appears to be quite reliable in identifying elites. To check the validity of this method, we consider a subset of households in our data that self-identify as holding formal leadership positions. These households also tell us their relatives in the hamlet. We can then ask what fraction of these households - who we know are true elite relatives would have been identified as elite relatives by at least two other respondents in our data. Of the 1,658 such households - i.e. the households named as family by survey respondents who selfidentify as formal elites $-1,303$ of them, or $79 \%$, were also identified as elite relatives by at least two other households in our survey. This cross-validation exercise suggests that measurement error in our elite variable is relatively small.

To identify program receipt for existing government programs, we collected detailed historical data on access to the larger targeted social programs: Raskin, Jamkesmas, and both rounds of the BLT. We also matched the baseline survey with information from two government administrative datasets. First, we obtained the 2008 PPLS data, which forms the official basis of targeting lists, and which included information on which households had been surveyed in 2008 as well as their poverty scores. Second, we obtained administrative data on the results of the PKH targeting processes (described below).

After the targeting experiments were completed, we conducted an endline survey for those households interviewed in the baseline in January 2012 to March 2012, which was also implemented by SurveyMeter. In this survey, we collected data on who actually received PKH, since the recipients could have differed from the targeting lists.

For comparison purposes, we use additional data from a prior experiment, described in Alatas et al (2012a). In that project, targeting was conducted in a low stakes environment, where beneficiary households received a one-time transfer of USD 3. 


\section{III.C. Experimental Design}

We designed an experiment to vary the level of elite control over targeting in a high-stakes environment, where selected households could expect to receive about US\$ 67-US\$250 per year for up to six years. We describe the experiment briefly here; details are provided in the Appendix. For the sample of 400 villages, we randomly assigned half to have targeting outcomes allocated through the current status quo for PKH: everyone who was surveyed in the last PPLS survey in 2008 was considered as a potential interviewee, along with households suggested by the local village leaders as poor. Central government officials then verified the poverty status of everyone on this combined list by conducting an asset survey and proxy-means test (PMT). ${ }^{7}$

In the remaining villages (community-input villages), the ultimate beneficiaries were determined not through a PMT, but rather through a community meeting with no additional verification. In particular, in each hamlet, meeting attendants determined the list of beneficiaries through a poverty-ranking exercise. After describing the PKH program, the facilitator began by displaying index cards listing the poorest households in the hamlet according to the official poverty census (PPLS 08), the same data source used in the status quo. The number of cards shown was roughly 75 percent of the sub-village's beneficiary quota. The meeting attendees then removed households with inaccurate information, i.e., households that a) no longer lived in the sub-village, or b) did not match at least one out of the three PKH demographic criteria. The facilitator then asked them to brainstorm a list of additional households they thought to be the most deserving of $\mathrm{PKH}$, up to 100 percent of the hamlet's quota. The facilitator then led the meeting through a process of ranking households on the combined lists of the initial and

\footnotetext{
${ }^{7}$ Due to cost considerations, this treatment was only conducted in the one randomly selected hamlet per village that we also surveyed in the baseline. To select beneficiaries in the other hamlets, the government used the 2008 PPLS.
} 
brainstormed households. ${ }^{8}$ The final recipient list was based on the rankings determined at this meeting, with no further verification by the central government.

To vary the level of elite control in the meetings, within the community-input villages, we randomly varied who was invited to them: in half of the villages, we asked the hamlet head to invite 5-8 local leaders, both formal and informal, to the meetings. In the other half, the full community was invited to the meetings so that they could potentially provide a check on the power of the elites to capture the targeting process. In the full community villages, the meetings were heavily advertised. For example, the facilitators often made door-to-door household visits. On average, 15 percent of households in the neighborhood attended the meetings in the elite subtreatment, while 59 percent did so in the community-input villages.

\section{RESULTS}

\section{III.A. Who Are the Local Leaders?}

Table 1 provides descriptive statistics from the baseline survey to illustrate the demographic characteristics and social participation levels of local leaders, and to compare them to the general population. In Column 1, we provide these summary statistics for non-elite-related households. We then provide these statistics for local leaders and their relatives (elites), by whether the leader is a formal (Column 2) or informal (Column 3). ${ }^{9}$ Finally, we provide these statistics for just the formal and informal local leaders themselves, respectively, in Columns 4 and 5.

\footnotetext{
${ }^{8}$ In a randomly selected half the villages, the original households on the PPLS list could not be kicked off by the ranking, so the ranking really only mattered for the additional brainstormed households. In the other half of villages, the lists were jointly ranked and households on the original PPLS list could be removed. The results are not substantively different between these two subtreatments. See the Appendix for more details.

${ }^{9}$ Note that 7.5 percent of those related to leaders are related to both formal and informal leaders; 1.33 percent of individual leaders were themselves listed as both formal leader and informal leaders.
} 
Panel A shows that local leaders and their relatives have somewhat higher levels of consumption than non-elite households. The local leaders and their relatives have consumption that is 9-11 percent higher than the non-elite households. Looking at just the leaders themselves (Columns 4 and 5), consumption is about 20 percent higher. While these differences are substantial, the standard deviation of log consumption for all groups is around 0.5 , meaning that the differences between elites and non-elites are less than one half of one standard deviation of the overall consumption distribution. Elite households also tend to own about 30 percent more land than non-elite households, though once again, these differences are swamped by the overall variance in land ownership among elites and non-elites.

Local leaders and their relatives are more likely to contribute to local public goods than non-elite households (Panel B). For example, they are more likely to participate in community projects, to contribute money to community projects, and to participate in religious activities. They are also more likely to belong to more community groups in the village (e.g. sport teams, religious study groups, etc.), though they spend slightly less hours in total participating in the groups. They are also more popular: When we asked baseline survey respondents to rank the other households in the hamlet based on how friendly they are, those households we subsequently identify as local leaders were generally ranked as friendlier than others. Interestingly, though, across all of these measures of social integration, we do not observe large differences between formal and informal leaders.

Finally, we asked individuals about their perceptions of corruption across different levels of government (Panel C), their general perception about how much they trust others (Panel D), and their perception of how fair a past targeted transfer program was (Panel D). We might expect that formal leaders, who are part of the government system, would have different perceptions of 
government than informal leaders, who typically operate outside of formal government institutions. In general, most people perceive that the central government is more corrupt than the local government (Panel C). We do not observe major differences in perceptions of corruption across the different types of households, although formal elites do tend to view the village government as slightly less corrupt than others (Panel C). We also do not find a substantial difference in the perception of trust across households (Panel D). There are differences, however, in the perception of the fairness in the 2008 BLT, one of the targeted transfer programs: leaders and their relatives were more likely to state that the program was fair than non-elites (Panel D). Interestingly, this is one area where we observe noticeable differences between formal and informal leaders: 71 percent of formal leaders were likely to state that they believed that the BLT was fair as compared to 60 percent of informal leaders (Columns 4 and 5). This is unsurprising, given that formal elites had a role in the targeting of BLT beneficiaries.

\section{III.B. Is There Elite Capture?}

In Table 2, we test for elite capture in targeted social programs using the following specification:

Eq 1: Beneficiary ${ }_{i v s}=\beta_{0}+\beta_{1}$ Elite $_{i v s}+\beta_{2} \ln (\text { Per Capita Consumption })_{i v s}+\alpha_{s}+\varepsilon_{i v}$ where Beneficiary ${ }_{i v s}$ is an indicator variable for whether the household is selected to be on the beneficiary list for the social program in question and Elite ivs $_{\text {is }}$ an indicator variable for whether the household is a formal or informal leader or is related to any type of leader. ${ }^{10} \mathrm{We}$ always include the log of per capita consumption, so that $\beta_{1}$, the key coefficient of interest,

\footnotetext{
${ }^{10}$ It is possible that there is measurement error in our measure of elite relatedness if households mis-identify elites and their relatives. Therefore, we replicate our regression analysis limiting elites to those who received four votes as elites, reducing the number of elites by about 30 percent. The findings, presented in Appendix Table 1, are similar to those presented in Table 2.
} 
provides an estimate of impact of being elite conditional on one's economic status. ${ }^{11}$ All regressions are estimated using OLS, include subdistrict fixed effects $\left(\alpha_{s}\right)$, and are clustered by village. $^{12}$

In Panel A, we begin by examining capture in Indonesia's existing social programs. We test for elite capture in the final allocations in four household targeted programs: BLT 2005, BLT 2008, Jamkesmas and Raskin in Columns $1-4$ respectively. We find that in BLT05, BLT08 and Raskin, elites are no more likely to receive benefits than non-elites. For Jamkesmas, conditional on consumption, elites are 2.9 percentage points ( 6.8 percent) more likely to receive benefits. ${ }^{13}$

In Panel B, we explore the results from the PKH targeting experiment that allowed varying degrees of elite capture. Specifically, we test for elite capture in the PMT treatment (Column 1) and the community-input treatment (Column 2), and then additionally report the differential effect of elite by whether the full communities or just local leaders were randomly invited to meeting where eligibility was determined (Column 3). The dependent variable is whether the household actually received $\mathrm{PKH}$, as measured from the endline survey. In all three cases, we find no evidence that the elite are more likely to receive benefits than they should be given their actual consumption levels. This is true even when only elites are invited to meetings to determine beneficiaries, and despite the very high stakes (almost $\$ 1000$ in NPV benefits) associated with obtaining benefits. In fact, in columns 1 and 2, the estimates suggest that elites

\footnotetext{
${ }^{11}$ If we did not control for consumption (Appendix Table 2), it would appear that leaders and their relatives would be less likely to be selected across the different programs, since all of the programs that we examine target to the poor to some extent and, as shown above, elites have higher per capita expenditure than non-elites.

${ }^{12}$ We study relatives because it is the clearest, exogenous measure of "relatedness" to village elites. It is possible that the elites may give to others in the community, such as their friends rather than relatives. To explore this, we ran a regression of beneficiary status on the number of social groups the households participated in jointly with the hamlet head, controlling for the log of per capita consumption, the total number of groups the hamlet head participates in, the total number of groups the household participated in, and a dummy for elite related. The results, presented in Appendix Table 3, show that those who participate in more social groups with the village head (conditional on their and the village head's total number of groups) are no more likely to become beneficiaries, providing further evidence for little to no elite capture.

${ }^{13}$ Note that consumption is a very strong predictor of beneficiary status even though it is likely measured with error and it is measured in a different time period than when the targeting occurred for the existing social programs.
} 
are less likely to receive benefits than they should be given their consumption level, although this effect becomes insignificant for the PMT treatment when we condition on additional control variables that may also be correlated with eligibility status (see Appendix Table 4). The coefficients on elite capture in the PMT treatment and the community treatment (e.g. Panel B, columns 1 and 2) are not statistically distinguishable. ${ }^{14}$

When programs are administered to households, it can often be the case that the final recipients of the transfers do not match the official targeting lists, as both central and local government staff may modify the lists prior to implementation. ${ }^{15}$ In columns 5-7 of Panel A, we examine this discrepancy by exploring elite capture in the government's PPLS 2008 targeting survey. Using these data, we simulate who would have been beneficiaries of a transfer program given perfect implementation of the lists. Since the distortions may differ at different points in the rank distribution, the level of elite capture may vary based on what poverty line is used, i.e. how many people will be targeted. As such, we vary the cutoffs for inclusion based on the standard cutoffs used in Indonesia: we use the "near poor" and below in Column 5 (36 percent of our sample), those below the poverty line in Column 6 (26 percent of our sample), and the "very poor" (defined as 80 percent of the poverty line) in Column 7 (about 10 percent of our sample). We find no evidence of elite capture on the PPLS list on any of these levels - if anything, once

\footnotetext{
${ }^{14}$ In the endline survey, 6 PMT villages were not surveyed due to transport difficult and safety concerns that were independent of the project. This does not affect our estimates of participation in existing Indoneisan government programs, nor the targeting lists in the PMT experiment. However, as we obtained PKH beneficiary status from the endline, it could affect our ability to compare the estimates of those who obtained PKH in the PMT treatment and those who obtained it in the community treatment (Panel B, Columns 1). To rule out differential selection in driving the results, we consider four strategies to drop equivalent villages in the community villages in Appendix Table 5: we drop all subdistricts that had more than one village dropped, we drop all subdistricts with greater than 10 percent of villages dropped, we drop all villages that have been dropped for these reasons across the two treatments in a new study we are conducting in the same villages, or we drop all subdistricts with more than 50 percent of villages dropped as well as those dropped in the new study. The results, shown in Appendix Tables 5 and 9, are consistent across all specifications.

${ }^{15}$ In the PKH experiment, 83 percent of households who were on the official targeting list in fact received the program, but there were some last minute changes. In particular, some additional funding became available, and many additional households were added to the list either through their status on the previous targeting survey (PPLS 08) or through informal mechanisms within the villages.
} 
again, there is a negative coefficient on the elite variable, suggesting that elites may be less likely to receive benefits.

In columns 5-7 of Panel B, we consider the analogous targeting lists from the $\mathrm{PKH}$ experiment - i.e. the official administrative data on who should have received benefits, as opposed to (in the previous columns) actual data on who received them. The results are similar, and if anything, show that the elite households are less likely to receive benefits than the nonelite ones. ${ }^{16}$

Finally, in Panel C, we compare our current findings with those from the low-stakes targeting experiment described in Alatas et al (2012a), where selected beneficiaries would receive a one-time transfer of US $\$ 3 .{ }^{17}$ In that experiment, which was conducted in different areas of Indonesia, we compared the targeting outcomes that arose from a full-census PMT (Column 5) where everyone in the village is interviewed by the central government versus a community method, where communities determine who should be a beneficiary unchecked by the government (Column 6). For those villages assigned to community-based targeting, we also randomly varied whether the full communities or just local leaders were invited to village meeting where eligibility was determined (Column 7). The results are very similar to the highstakes experiment reported in Panel B, and show no evidence of elite capture.

\section{III.C. Do Formal and Informal Leaders Behave Differently?}

The analysis thus far has treated all local elites the same. However, formal and informal leaders may behave differently. Individuals who select to enter formal government service may be

\footnotetext{
${ }^{16}$ The PMT treatment in the PKH experiment used the same methodology as the PPLS 2008. If we expect that leaders learn how to capture targeting programs over time as they learn the system, we would have expected more capture in the PKH experiment, conducted in 2011, than in the 2008 PPLS survey (Camacho and Conover, 2009). This was not the case.

${ }^{17}$ We ensured that everyone who was on the targeting list received the transfer in the experiment.
} 
different from those who become leaders informally through community service. They may also be subject to different types of constraints: formal leaders may be subject to political constraints, while the influence and power of informal leaders is subject to social acceptance and pressures.

In Table 3, we compare elite capture by formal versus informal leaders. Specifically, we replicate the analysis in Table 2, but re-define the elite variable based on the types of leadership role the household (or their relatives) possess. ${ }^{18}$ Note that we again control for log per capita consumption, even though it is not included in the table for brevity.

We begin by considering the existing government programs, with Panel A showing results for formal elites and Panel B showing results for informal elites. We find that, conditional on per capita consumption, for the most part, formal leaders and their relatives are more likely to be beneficiaries, while informal elites are less likely to. ${ }^{19}$ For example, formal leaders and their relatives are almost 5 percentage points more likely to receive BLT, the direct cash assistance program, in both years that it was administered (Columns 1 and 2); 8 percentage points more likely to receive Jamkesmas, the health insurance program for the poor (Column 3); and 3 percentage points more likely to receive the subsidized rice program, Raskin (Column 4). In contrast, informal elites are about 6 to 7 percentage points less likely to receive all four programs.

The remaining columns of Panels A and B show the result from the PPLS official targeting list. Intriguingly, there is no evidence of elite capture in the targeting lists at any of the three levels we examine in the official targeting list. This suggests that the difference between informal and formal elites, and in particular the capture by formal elites, comes in the implementation of the program, not during the official targeting process.

\footnotetext{
${ }^{18}$ In Appendix Table 6, we replicate Table 3, redefining the elite variable to consist only of households that are themselves judged to be local leaders as elites, rather than the local leaders and their relatives. The findings are similar to Table 3 .

${ }^{19}$ The findings are similar when we control for additional household characteristics (Appendix Table 7, Panels D).
} 
Panels $\mathrm{C}$ and $\mathrm{D}$ explore the results of the PKH experiment. Interestingly, we find no evidence of capture in the PKH experiment for formal or informal elites, either in the actual allocation of beneficiaries or in the official targeting list, in any of the treatments. ${ }^{20}$ One potential explanation for the difference between these results and the results on existing government programs in Panel A and B is that the threshold for being a beneficiary is much lower: in the PKH program, only about 12 percent of households in our data received benefits, compared to 36 percent for BLT, 42 percent for Jamkesmas, and 75 percent for Raskin. While elites may be able to plausibly pretend to be in the middle of the income distribution, it may be much harder to plausibly pretend to be in the bottom decile. ${ }^{21}$

Note that in addition to variation across programs in the slots available, there is natural variation within programs as to the number of slots that the village receives relative to its actual number of poor. Specifically, due to errors in calculating slots and negotiations that happen at the district and sub-district level, some villages receive an "over-quota" of slots relative to the actual number of their poor. We can test whether we observe a correlation between elite capture and whether the village was over-quota. ${ }^{22}$ Table 4 provides these results for all elites (note that Appendix Table 10 provides these results disaggregated by formal and informal elites). In Panel A, we interact the elite variable with a dummy for being more than 50 percent over the quota, while in Panel B, we interact it with a simple indicator variable for being over quota. We find

\footnotetext{
${ }^{20}$ Appendix Table 8 provides this analysis for the low-stakes experiment in Alatas et al (2012). We find that both informal and formal leaders are less likely to be selected to be on the list, particularly on the community treatment.

${ }^{21}$ Another potential explanation is that there was relatively little leeway in the PKH program to add beneficiaries beyond the official targeting process, compared to the amount of ex-post discretion allowed in BLT, Raskin, and Askeskin, which all essentially have mechanisms that allow village leaders to add beneficiaries during the program implementation. This would be consistent with the results in Panel A and B that official targeting lists do not show signs of capture, while actual program implementation does.

${ }^{22}$ We compute the over-quota variable by comparing BLT 08 village allocation quota with the quota that should be given in that village. The allocation quota data for each village comes from PPLS 08 data which give us about 30 percent of household population or 18.5 million households. To generate the quota that should have been given to each village, we first calculate the share of the districts quota that should have been given to a given village from a poverty map exercise using census 2010 data, and then scale that with the district quota predicted by SUSENAS to have equivalent poverty lines. Those who have more slots relative to actual poverty line are considered over-quota.
} 
suggestive evidence that there is more elite capture in areas where there are more slots relative to the poverty line, particularly for the cash transfer program in 2005 (Column 1) and health insurance program (Column 3). The effects are generally larger and more significant when we consider only those with a large number of slots relative to the poverty line (i.e. those with slots that are 150 percent times the poverty line) in Panel A.

Taken together, these findings lead to several key conclusions. First, informal elites, who gain influence on their moral standing within the village community and therefore value their reputation, appear less likely to be engaged in capture than formal elites. Second, the elite capture by formal leaders that we observed occurred at the allocation stage, rather than within the targeting process. This suggests that reducing elite capture at the targeting stage, without a coupled intervention to ensure that those who are targeted actually receive the program, would be ineffective in achieving the ultimate goal of ensuring that the transfer end up in the hands of the poor. Third, capture by formal elites happens in programs - Jamkesmas and BLT - which cover about 35 percent of the population, and not in programs (like PKH) which cover a much poorer segment of society and when there are many fewer slots, and related to this, we find more formal elite capture in areas that received more slots relative to their poverty line. There can be several explanations for these findings. A generous one is that the formal elites only steal when there is enough left over after taking care of the poor. A more cynical one is that it is hard for formal elites to plausibly pretend to be very poor, whereas it is possible to pass a relatively richer person off as a potential program beneficiary when the cutoff is higher up the income distribution.

\section{III.D. Elections as a Constraint on Capture}


Within the Indonesian context, there is variation in how formal elites derive their power. Indonesia has two local governmental structures-desa, which are primarily rural and in which the head is elected, and kelurahan, which are primarily urban and in which the head is a civil servant appointed by the district government. While desa are primarily rural and kelurahan are primarily urban, these structures are slow to respond to demographic changes and the match is not perfect, so there are some urban desa and some rural kelurahan (Martinez-Bravo, 2012). Since the village head appoints much of the formal village structure, we utilize these different institutional structures to test whether elections constrain capture by formal elites. ${ }^{23}$

Specifically, while both types of leaders may be subject to pressures to promote pro-poor targeting and resist elite capture, the elected leaders may face greater political pressures to do so than those who are appointed. Therefore, we in Table 5A and 5B, we test whether elites are less likely to be beneficiaries, conditional on consumption, when the village leaders are elected:

$$
\begin{gathered}
\text { Eq 2: Beneficiary } \text { fivs }=\beta_{0}+\beta_{1} \text { Elite }_{i v s}+\beta_{2} \ln (\text { Per Capitia Consumption })_{i v s}+ \\
\beta_{3} \text { Elite }_{i v s} * \text { Elected }_{v s}+\beta_{4} \text { Elected }_{v s}+\beta_{5} \text { Elite }_{i v s} * \text { Urban }_{v s}+\beta_{6} \text { Urban }_{v s}+\alpha_{s}+\varepsilon_{i v}
\end{gathered}
$$

where $_{\text {Elected }}$ is is a dummy variable for whether the village leader was elected. Since whether the village leader is elected is highly correlated with urban status, we additionally include an indicator variable for whether the village is urban, as well as the interaction between the indicator variables for elite and urban. All regressions are estimated by OLS, include strata fix effects, and are clustered at the village level. In Table 5A, we present results for existing government programs, and in Table 5B, we present results for the PKH experiment.

\footnotetext{
${ }^{23}$ In both cases (elected and non-elected), the village head usually appoints the village staff (secretary, heads of various divisions, and consultative body). However, even if others who are formal leaders within the village are not elected, the fact that the village leader (their boss) is elected may impose additional pressure on them to respond to the citizenry. Neighborhood heads are elected in both desa and keluarahan. As an addition robustness check, we reestimate the model dropping the RT head from the analysis (Appendix Table 11); the findings are similar to the main table.
} 
Overall we do not find that elections constrain officials. We find no differential effect of the village leader being elected on whether the elites are more likely to be on the targeting list (Table 5A, Panel A, Columns 5-7) or receive the unconditional cash transfer program (BLT) in 2005 or 2008 (Table 5A, Panel A, Columns 1 and 2). If anything, we find that formal elites are more likely to be beneficiaries for the Jamkesmas and Raskin (Table 5A, Panel B, Columns 3 and 4) in villages where the village leadership is elected. Similarly, we find that all elites are more likely to be on the targeting list for PKH in the villages with PMT targeting (Table 5B, Column 4) if the village leadership was elected. In sum, we do not find any evidence in favor of the notion that elections constrain elites. Note that this is consistent with the finding that there is more elite capture by formal elites than informal elites, as social pressure from communities may be more effective in keeping informal leaders in check than elections.

\section{III.E. Other forms of patronage}

Thus far, we have focused on elite capture in the form of leaders putting themselves or their relatives on beneficiary list. However, other types of patronage are also possible: leaders may provide patronage to certain individuals or groups other than those related to them. Patronage is difficult to observe since we do not know who, ex ante, these people may be. However, if patronage exists and is large in magnitude, we would expect that the observed distribution of characteristics of the beneficiaries chosen by elites and non-elites would appear to be different.

In Table 6, we use the elite and non-elite meeting subtreatments in the PKH experiment to test for this. ${ }^{24}$ We first examine whether leaders and non-leaders have different perceptions of who is poor outside of the context of targeting. This is important since if they have different information on who is poor, or if they place different weights on this information in determining

\footnotetext{
${ }^{24}$ All regressions are estimated using OLS, include a strata fixed effect and are clustered at the village level.
} 
income status, we would expect to observe differences in targeting that are independent of patronage. Thus, we begin by reporting the coefficients from a regression of all households' average perceived rank in the income distribution on household characteristics as reported by leader (Column 1) and non-leader (Column 2) survey respondents. Note that these ranks were collected in the baseline survey, and not connected to any program, so they represent beliefs on the income distribution that are independent of targeting.

As Columns 1 and Columns 2 indicate, leaders and non-leaders have very similar perceptions about what how characteristics affect a household's income level. Across both regressions, the coefficients estimates are strikingly similar both in magnitude and significance. A joint test across these differences yields a p-value of 0.02 , suggesting that at least one of the characteristics differs across leaders and non-leaders. Looking more closely at the data, out of the 23 characteristics, five are statistically significant at the 10 percent level (household size, hardworkingness, friendliness, disabled, being an ethnic minority), but the magnitude of these differences is small. Thus, given that the perceptions of poverty status are, for the most part, fairly similar, we would also expect that the distribution of characteristics of targeted households would look similar during targeting absent patronage.

To test this, we replicate this analysis where the outcome variable is now whether the household was selected as a program beneficiary during the elite only (Column 3) and the full community meeting (Column 4). We would expect that it would be easier for elites to siphon funds to different groups when the meeting is behind closed doors, as opposed to when the full community is present to potentially provide a check on the elites.

Comparing the beneficiary status across the two types of meetings, we find that the characteristics of households who receive PKH do not appear to be different regardless of 
whether the full community is present at the meeting or only the elites are present (Columns 3 and 4). The joint test conforms that the characteristics of those selected does not systematically differ across the two groups ( $\mathrm{p}$-value $=0.17$ ) implying that it is unlikely the elite treatment induced other types of patronage in this setting. Finally, we explore who was on the official targeting lists for PKH (columns 5 and 6). Again, we find no difference in the characteristics of those selected across the two subtreatments ( $\mathrm{p}$-value $=0.77$ ).

\section{BENCHMARKING ELITE CAPTURE RELATIVE TO TARGETING ERROR}

On net, we find evidence that the formal elites are more likely to receive transfers, conditional on their consumption level, during the implementation of certain targeted transfer programs. We now ask whether this level of capture is economically significant, and compare the potential welfare losses due to elite capture to those from other types of errors in the targeting process.

Before proceeding with a more formal welfare calculation, we begin with a simple back of the envelope calculation: by how much does elite capture change the average per-capita consumption level of those receiving benefits? To calculate this, we note that formal leaders and their relatives are only 9 percent richer than non-elites, are at most about 8 percentage points (the highest is in the case of health insurance) more likely to receive benefits than non-elites at a given consumption level, and represent at most 15 percent of the population. Given this, a back-

of-the-envelope way to measure elite capture is to consider how different the average consumption level of program beneficiaries would be if the advantage formal elites have was eliminated. Roughly, it would be 0.15 (share of elites in population) $\times(0.08 / 0.42)$ (relative increase in elite's probability of receiving the program) $\times 0.09$ (elite consumption relative to 
non-elite consumption) $=0.003$ higher, or about three tenths of a percentage point higher with elite capture than without it. $^{25}$

To calculate the impact of elite capture more formally, we consider the following welfare calculation. We assume a CRRA utility function with $\rho=3$, and calculate utility for all households in our sample without the program. Next, we calculate expected utility from each social program, both with and without elite capture. To do so, for each household, we first calculate their predicted probability of receiving benefits from a given program as estimated using equation (1), and their predicted probability of receiving benefits from the same econometric model setting the ELITE variable equal to 0 (that is, without an elite premium). ${ }^{26}$ Since the sum of the probabilities will be slightly different under these two scenarios, we scale the probabilities with elite related off such that the sum of the probabilities in both scenarios is identical; that is, we keep the total number of beneficiaries the same with and without capture, but just change the probability a given household receives benefits. We then assign each household the per-capita monthly benefits from a given program with probability equal to the predicted probability, and then calculate the total utility under the program with and without elite capture using the two different predicted probabilities (one with ELITE $=1$ for elites, and one under the hypothetical

\footnotetext{
${ }^{25}$ To see this, define $c_{b}$ to be the consumption of the beneficiaries with no differential elite capture, and $c_{e}$ to be the consumption of elites, $\beta$ to be the average probability that people in the population receive benefits and $\Delta \beta$ to be additional probability that elites receive benefits, and $\alpha_{e}$ the population share of elites. With elite capture the average consumption of beneficiaries is $\frac{\beta c_{b}+\alpha \Delta \beta c_{e}}{\beta+\alpha \Delta \beta}$, and without elite capture the average consumption of beneficiaries is just $c_{b}$. The percent difference in average consumption is just $\frac{\frac{\beta c_{b}+\alpha \Delta \beta c_{e}}{\beta+\alpha \Delta \beta}-c_{b}}{c_{b}}=\frac{\alpha \Delta \beta \frac{\left(c_{e}-c_{b}\right)}{c_{b}}}{\beta+\alpha \Delta \beta}<\alpha \frac{\Delta \beta}{\beta} \frac{\left(c_{e}-c_{b}\right)}{c_{b}}$, which is the percentage calculated in the text. Note that in this back-of-the-envelope calculation we have used average elite consumption relative to average non-elite consumption; more formally, one should use the consumption of elite beneficiaries relative to non-elite beneficiaries. This is done in the formal welfare calculation in the text.

${ }^{26}$ Since we will be predicting probabilities, for this exercise we use probit specifications with all of the controls variables used in Appendix Table 3. We use probit, rather than OLS, so that all predicted probabilities are bounded between 0 and 1. We provide the coefficient estimates from the probit in Appendix Table 12. The Probit results are similar to the main results reported in the text.
} 
counterfactual that there was no differential benefit for elite, i.e. setting the ELITE variable to 0 in predicting probabilities).

We also compute two benchmarks. First, we calculate what the utility would be if we chose the poorest households to become beneficiaries based on their baseline consumption levels. This is effectively the utility from the program under "perfect" targeting. However, it is near impossible to achieve perfect targeting in the real world, since it is impossible to conduct a reliable consumption survey in a high-stakes environment when it is being used for targeting. Thus, as a second benchmark, we calculate utility if the government conducted a high-quality proxy-means test for the entire population. To do so, we calculate each household's predicted proxy-means test score using the asset variables we observe in the survey, which was conducted by a highly reputable survey company, and the PMT formula used in PKH. Then, we assign the benefits to those households with the lowest PMT score.

Table 7 presents these calculations. We present the results for all elites, formal elites and informal elites in Panels A through C, respectively. Each column shows a different simulation for a different program. For each program, the first 5 rows show the utility without the program, with the program given the actual elite effects we estimate in the data, with the program but without any differential effect for elites, under more complete proxy-means test targeting (giving benefits to those with lowest proxy-means test scores), and under perfect consumption targeting (giving benefits to those with lowest consumption). The final three rows show the share of the possible utility gain each scenario obtains, where 0 is the utility without the program and $100 \%$ is the maximum utility with the program under perfect consumption targeting.

The difference due to elite capture can be seen by comparing the share of the possible utility gain with elite related on to the share of possible utility gain with elite related off. 
Focusing on formal elites - the only place we saw elite capture - the differences are small (Panel B). For the PKH experiment, the difference is -0.23 percentage points $(26.58 \%$ with elite related on vs. $26.35 \%$ with elite related off); for Jamkesmas, the difference is 1.18 percentage points (61.75\% vs. $62.93 \%$ ); for Raskin, 0.46 percentage points ( $88.33 \%$ vs. $88.79 \%$ ); for BLT05, 0.61 percentage points $(57.37 \%$ vs. $57.98 \%)$; for BLT $08,0.68$ percentage points $(60.20 \%$ vs. 60.98\%). Averaging across all 5 programs, eliminating formal elite capture entirely would improve welfare by about 0.54 percentage points, or about seven tenths of one percen 3 t.

To put these numbers in perspective, it is worth considering how large the potential scope for improvement is by simply improving overall targeting. We consider as the benchmark targeting based on assets using a proxy means test since perfect consumption targeting is often impossible. If the proxy means test was implemented perfectly - that is, the poorest households according to proxy means test scores received benefits - our data suggest that welfare from Jamkesmas would improve by 17 percentage points ( 27 percent); welfare from Raskin by 7 percentage points ( 8 percent); welfare from BLT05 by 18 percentage points (32 percent); and welfare from BLT08 by 17 percentage points (28 percent). ${ }^{27}$

In sum, eliminating elite capture will not improve welfare as much as improving administrative capabilities to administer the PMT. In particular, the results suggest that the possible welfare gains from improved targeting implementation are more than 20 times larger

\footnotetext{
${ }^{27}$ Note that this better-implemented proxy-means test is different from the actual procedure along two dimensions. First, it uses data for all households, rather than just those who are chosen to be interviewed by the village government. Second, it uses data from a reputed survey company rather than the government enumerators. For $\mathrm{PKH}$, we can also explore the welfare gains if only those the government suggested are interviewed, but we use the asset data that comes from our baseline survey rather than the government survey to calculate the PMT scores. These results, which are presented in Appendix Table 13, show that most of the welfare gains that can be achieved with the perfectly implemented PMT are due to just imperfect data quality, and not due to the full census: the welfare gain from the perfectly implemented, full census PMT is 41.71 percent while the welfare gain of just the perfectly implemented PMT over the selected sample that is interviewed in the national survey is 36.99 percent.
} 
than the potential welfare gains from the complete elimination of elite capture in these programs, and therefore suggest that investing in higher quality data collection mechanisms is important.

\section{CONCLUSION}

Despite the high perceived level of corruption in Indonesia, we find little evidence of local elite capture of household targeted programs. This finding holds up across the largest, national household targeted programs in Indonesia, where elites appear to have considerable influence over the allocation, as well as in our community-based targeting experiments, in which elites are in some cases the only people invited to the meetings at which targeting decisions are made.

However, not all elites are the same: we find that elites who operate within the formal system are more likely to capture programs, while those who gain their power and influence through informal institutions are less likely to. Interestingly, the manipulation of the system occurs at the implementation stage of the programs where additional households are added and subtracted to the list, and not during the targeting surveys.

Regardless of whatever elite capture we do find, the type of capture we study here is not economically large: eliminating elite capture of the beneficiary list altogether would increase the welfare gains from these programs by at most about one percent. Of course there is no reason to think that this is simply the result of the good-will of the elites. The fear of popular disapproval or even reprisals, either by the villagers themselves, through the electoral mechanism or through other means, or by higher levels of government, probably plays an important role in disciplining them. The point is however that the existing system of incentives is adequate in severely limiting the amount of resources they manage to extract. 
Our results have two important implications. First, there is the question of priorities: Starting from where we are today, any further focus on limiting elite capture may be less important than improving administrative practices that have nothing to do with elites: as we saw, the welfare loss from capture is small relative to the targeting error induced by administrative capabilities, both in terms of the quality asset data collected and in terms of our ability to predict consumption using asset measures. Second, in designing effective public delivery mechanisms there is often a reluctance to engage the local elites for fear of capture. However, we should take seriously the possibility that improving the skills of local leaders through training them and challenging them to perform by giving them important responsibilities may contribute more to welfare than cutting them out of the whole process to avoid capture, even if this means that the elites sometimes pocket some of the resources, because at least in the context we study the consequences of elite capture are simply not bad enough to give up everything else to prevent it. Given the importance of national leaders (Jones and Olken 2005), and the fact that national leaders often start as local leaders (e.g., Myerson 2009), the small welfare costs of elite capture documented here suggests worrying less about capture by local elites.

\section{WORKS CITED}

Acemoglu, Daron. 2006. "A Simple Model of Inefficient Institutions." The Scandinavian Journal of Economics 108: 515-546.

Acemoglu, Daron, Simon Johnson, and James A. Robinson. 2005. "The Rise of Europe: Atlantic Trade, Institutional Change and Economic Growth." American Economic Review 95 546-579.

Growth 1a: 385-472.

, Institutions as a Fundamental Cause of Long-Run Growth." Handbook of Economic 
Acemoglu, Daron, Tristan Reed, and James A. Robinson. 2012. "Chiefs.” Mimeo, MIT.

Alderman, Harold, 2002. "Do Local officials know something we don't? Decentralization of targeted transfers in Albania." Journal of Public Economics 83 (3): 375-404.

Alatas, Vivi, Abhijit Banerjee, Rema Hanna, Benjamin A. Olken, and Julia Tobias. 2012a. "Targeting the Poor: Evidence from a Field Experiment in Indonesia." American Economic Review 104 (2), pp 12061240.

Alatas, Vivi, Abhijit Banerjee, Rema Hanna, Benjamin A. Olken, Ririn Purnamasari, and Matthew WaiPoi. 2012b. "Ordeal Mechanisms in Targeting: Theory and Evidence from a Field Experiment in Indonesia." Mimeo, MIT.

Bardhan, Pranab, and Dilip Mookherjee, 2000 "Relative Capture of Government at Local and National Levels". American Economic Review 90.

Bardhan, Pranab, and Dilip Mookherjee. 2005. "Decentralizing antipoverty program delivery in developing countries." Journal of Public Economics 89: 675-704.

Bardhan, Pranab, and Dilip Mookherjee. 2006. "Pro-poor Targeting and Accountability of Local Governments in West Bengal." Journal of Development Economics 79: 303-27.

Besley, Timothy, Rohini Pande and Vijayendra Rao. 2007. "Just Rewards? Local Politics and Public Resource Allocation in South India." Development Economics Papers, Suntory and Toyota International Centres for Economics and Related Disciplines, LSE.

Caeyers, Bet and Dercon, Stefan. 2011. "Political Connections and Social Networks in Targeted Transfer Programmes: Evidence from Rural Ethiopia." Economic Development and Cultural Change. (forthcoming)

Casey, K., R. Glennerster, and E. Miguel. 2011. "Reshaping Institutions: Evidence on Aid Impacts Using a Pre-Analysis Plan.” NBER Working Paper Series 17012.

Coady, David, Margaret Grosh and John Hoddinott. 2004. "Targeting Outcomes Redux."

WorldBank Research Observer 19: 61-86.

Daly, Anne and George Fane, "Anti-Poverty Programs in Indonesia, 2002. "Bulletin of Indonesian Economic Studies 38 (3): 309-329.

Dreze, Jean and Amartya Sen. Hunger and Public Action. Oxford: Oxford University Press, 1989.

Faguet, Jean Paul G. "Does Decentralization Increase Government Responsiveness to Local Needs? Evidence from Bolivia." Journal of Public Economics 88 (2004): 867-893.

Foster, Andrew, and Mark Rosenzweig. 2004. "Democratization and the Distribution of Local Public Goods in a Poor Rural Economy." Brown University Working Paper.

Galasso, Emanuela and Martin Ravallion, 2005. "Decentralized targeting of an antipoverty program," Journal of Public Economics 89 (4): 705-727. 
Henisz, Witold. "The Institutional Environment for Economic Growth." Economics and Politics 12 (2000): 1-31.

Jones, Benjamin F. and Benjamin A. Olken. 2005. "Do LeadersMatter? National Leadership and Growth since World War II,.” Quarterly Journal of Economics 120 (3), 835-864.

Khwaja, Asim, forthcoming. "Can Good Projects Succeed in Bad Communities?" Journal of Public Economics.

Martinez-Bravo, Monica, 2012. "The Role of Local Officials in New Democracies: Evidence from Indonesia", mimeo, Johns Hopkins.

Martinez-Bravo, Monica, Gerard Padro I Miquel, Nancy Qian, and Yang Yao. 2011. "Do Local Elections in Non-Democracies Increase Accountability? Evidence from Rural China," mimeo, LSE.

Myerson, Roger, 2009. "Local Foundations for Strong Democracy in Pakistan." Mimeo, University of Chicago.

Niehaus, Paul, Antonia Atanassova, Marianne Bertrand, and Sendhil Mullainathan, forthcoming. "Targeting with Agents." American Economic Journal: Economic Policy.

North, Douglass C. and Barry R. Weingast. "Constitutions and Commitment: The Evolution of Institutions Governing Public Choice in 17th Century England." Journal of Economic History 49 (1989): 803-32.

Olken, Benjamin A. 2006. "Corruption and the Costs of Redistribution." Journal of Public Economics 90 (4-5), pp 853-870.

Olken, Benjamin A. "Direct Democracy and Local Public Goods: Evidence from a Field Experiment in Indonesia.” American Political Science Review 104 (2010): 243-67.

Persson, T., G. Roland and G. Tabellini. "Separation of Powers and Political Accountability." Quarterly Journal of Economics 112 (1997): 1163-1202.

Rosenzweig, M and Munshi, K. 2010. “ Networks, Commitment, and Competence: Caste in Indian Local Politics.” Brown University Working Paper.

World Bank. 2004. World Development Report 2004: Making Services Work For Poor People. Washington, DC, World Bank. 


\begin{tabular}{|c|c|c|c|c|c|}
\hline \multirow[t]{2}{*}{ (2) } & \multirow[b]{2}{*}{$\begin{array}{c}\text { Non-Elite } \\
\text { (1) }\end{array}$} & \multicolumn{2}{|c|}{ Leaders and their Relatives } & \multicolumn{2}{|c|}{ Leaders } \\
\hline & & $\begin{array}{c}\text { Formal } \\
(2)\end{array}$ & $\begin{array}{l}\text { Informal } \\
\text { (3) }\end{array}$ & $\begin{array}{l}\text { Formal } \\
\text { (4) }\end{array}$ & $\begin{array}{c}\text { Informal } \\
(5)\end{array}$ \\
\hline \multicolumn{6}{|c|}{ Panel A: Socio-Economic Status } \\
\hline Log (Per Capita Consumption) & 13.09 & 13.18 & 13.20 & 13.27 & 13.25 \\
\hline & {$[0.53]$} & {$[0.52]$} & {$[0.56]$} & {$[0.53]$} & {$[0.60]$} \\
\hline & 2579 & 1019 & 700 & 516 & 276 \\
\hline Land owned (in hectare) & 0.39 & 0.52 & 0.51 & 0.62 & 0.43 \\
\hline & {$[1.70]$} & {$[1.31]$} & {$[1.54]$} & {$[1.64]$} & {$[0.92]$} \\
\hline & 2581 & 1019 & 700 & 516 & 276 \\
\hline \multicolumn{6}{|c|}{ Panel B: Community Integration } \\
\hline Participate in community projects & 0.70 & 0.81 & 0.82 & 0.90 & 0.84 \\
\hline & {$[0.46]$} & {$[0.39]$} & {$[0.38]$} & {$[0.30]$} & {$[0.37]$} \\
\hline & 2581 & 1019 & 700 & 516 & 276 \\
\hline \multirow[t]{3}{*}{ Contribute money } & 0.29 & 0.44 & 0.45 & 0.55 & 0.51 \\
\hline & {$[0.45]$} & {$[0.50]$} & {$[0.50]$} & {$[0.50]$} & {$[0.50]$} \\
\hline & 2581 & 1019 & 700 & 516 & 276 \\
\hline \multirow[t]{3}{*}{ Participate in religious activities } & 0.54 & 0.71 & 0.71 & 0.77 & 0.76 \\
\hline & {$[0.50]$} & {$[0.45]$} & {$[0.45]$} & {$[0.42]$} & {$[0.43]$} \\
\hline & 2581 & 1019 & 700 & 516 & 276 \\
\hline \multirow[t]{3}{*}{ Participate in number of groups $(0-7)$} & 1.21 & 2.12 & 1.94 & 2.75 & 2.14 \\
\hline & {$[1.04]$} & {$[1.46]$} & {$[1.39]$} & {$[1.40]$} & {$[1.33]$} \\
\hline & & & & & \\
\hline \multirow{2}{*}{ Hours spent on group activities (per day) } & 1.81 & 1.53 & 1.29 & 1.63 & 1.25 \\
\hline & $\begin{array}{l}{[9.03]} \\
2581\end{array}$ & $\begin{array}{c}{[4.56]} \\
1019\end{array}$ & $\begin{array}{c}{[3.85]} \\
700\end{array}$ & $\begin{array}{c}{[2.01]} \\
516\end{array}$ & $\begin{array}{c}{[1.36]} \\
276\end{array}$ \\
\hline \multirow{3}{*}{ Friendliness (1-10, 1 least) } & 4.75 & 6.12 & 5.86 & 6.87 & 6.20 \\
\hline & [1.49] & [1.65] & [1.73] & {$[1.51]$} & {$[1.65]$} \\
\hline & 2579 & 1019 & 698 & 516 & 275 \\
\hline \multicolumn{6}{|c|}{ Panel C: Perception of Corruption in Different Levels of Government ( 1 is low, 4 is high) } \\
\hline \multirow[t]{3}{*}{ Central government corruption } & 3.30 & 3.29 & 3.35 & 3.36 & 3.41 \\
\hline & [0.82] & [0.84] & [0.75] & {$[0.80]$} & {$[0.70]$} \\
\hline & 2254 & 930 & 629 & 485 & 258 \\
\hline \multirow[t]{3}{*}{ District government corruption } & 2.71 & 2.62 & 2.69 & 2.60 & 2.64 \\
\hline & {$[0.88]$} & {$[0.87]$} & {$[0.85]$} & {$[0.86]$} & {$[0.84]$} \\
\hline & 2018 & 854 & 552 & 450 & 223 \\
\hline \multirow[t]{3}{*}{ Village government corruption } & 2.00 & 1.76 & 1.86 & 1.64 & 1.79 \\
\hline & {$[0.84]$} & {$[0.79]$} & {$[0.78]$} & {$[0.74]$} & {$[0.73]$} \\
\hline & 2115 & 916 & 595 & 487 & 234 \\
\hline \multicolumn{6}{|c|}{ Panel D: Perception of Trust and BLT2008 fairness } \\
\hline \multirow{3}{*}{$\begin{array}{l}\text { Trust (binary; } 1 \text { if respondent thinks people can } \\
\text { generally be trusted) }\end{array}$} & 0.06 & 0.05 & 0.05 & 0.06 & 0.06 \\
\hline & [0.23] & {$[0.22]$} & {$[0.23]$} & {$[0.23]$} & {$[0.23]$} \\
\hline & 2581 & 1019 & 700 & 516 & 276 \\
\hline \multirow[t]{3}{*}{ BLT 2008 fairness (binary; 1 if fair) } & 0.52 & 0.63 & 0.62 & 0.71 & 0.60 \\
\hline & {$[0.50]$} & {$[0.48]$} & [0.48] & {$[0.45]$} & [0.49] \\
\hline & 2417 & 992 & 656 & 510 & 258 \\
\hline
\end{tabular}

Notes: This table provides baseline summary statistics on elite versus non-elite households. Means are listed, followed by standard deviations in brackets, and the number of observations. 
Table 2: Do Elite Capture Targeted Programs?

\begin{tabular}{|c|c|c|c|c|c|c|c|}
\hline & $(1)$ & $(2)$ & (3) & $(4)$ & $(5)$ & (6) & $(7)$ \\
\hline & \multicolumn{7}{|c|}{ Panel A: Government Transfer Programs } \\
\hline & \multicolumn{4}{|c|}{ Receives Benefits } & \multicolumn{3}{|c|}{ Targeting Lists } \\
\hline & BLT05 & BLT08 & Jamkesmas & Raskin & PPLS 1 & PPLS 2 & PPLS 3 \\
\hline \multirow{2}{*}{ Elite } & 0.003 & 0.006 & $0.029 *$ & -0.006 & 0.004 & $-0.028 * *$ & $-0.018 *$ \\
\hline & $(0.016)$ & $(0.017)$ & $(0.017)$ & $(0.013)$ & $(0.016)$ & $(0.014)$ & $(0.010)$ \\
\hline \multirow[t]{2}{*}{ Log Consumption } & $-0.194 * * *$ & $-0.200 * * *$ & $-0.185 * * *$ & $-0.204 * * *$ & $-0.204 * * *$ & $-0.172 * * *$ & $-0.081 * * *$ \\
\hline & $(0.014)$ & $(0.014)$ & $(0.014)$ & $(0.014)$ & $(0.014)$ & $(0.013)$ & $(0.010)$ \\
\hline Observations & 3,985 & 3,985 & 3,996 & 3,996 & 3,996 & 3,996 & 3,996 \\
\hline \multirow[t]{4}{*}{ Dependent Variable Mean } & 0.362 & 0.387 & 0.425 & 0.751 & 0.359 & 0.262 & 0.102 \\
\hline & \multicolumn{7}{|c|}{ Panel B: PKH Experiment } \\
\hline & \multicolumn{3}{|c|}{ Receives PKH } & & \multicolumn{3}{|c|}{ Targeting List PKH } \\
\hline & PMT & Community & Community & & PMT & Community & Community \\
\hline \multirow[t]{2}{*}{ Elite } & $-0.032 * *$ & $-0.042 * * *$ & -0.029 & & $-0.017^{*}$ & $-0.030 * *$ & $-0.029 *$ \\
\hline & $(0.015)$ & $(0.015)$ & $(0.021)$ & & $(0.009)$ & $(0.011)$ & $(0.017)$ \\
\hline \multirow[t]{2}{*}{ Log Consumption } & $-0.096 * * *$ & $-0.124 * * *$ & $-0.124 * * *$ & & $-0.035 * * *$ & $-0.074 * * *$ & $-0.074 * * *$ \\
\hline & $(0.015)$ & $(0.015)$ & $(0.015)$ & & $(0.009)$ & $(0.012)$ & $(0.012)$ \\
\hline \multirow[t]{2}{*}{ Elite Subtreatment } & & & -0.005 & & & & -0.013 \\
\hline & & & $(0.024)$ & & & & $(0.019)$ \\
\hline \multirow[t]{2}{*}{ Elite $x$ Elite Subtreatment } & & & -0.027 & & & & -0.001 \\
\hline & & & $(0.029)$ & & & & $(0.023)$ \\
\hline Observations & 1,863 & 1,936 & 1,936 & & 1,996 & 2,000 & 2,000 \\
\hline \multirow[t]{4}{*}{ Dependent Variable Mean } & 0.110 & 0.142 & 0.142 & & 0.0431 & 0.0770 & 0.0770 \\
\hline & & & & Panel C: Lo & experiment & & \\
\hline & & & & & \multicolumn{3}{|c|}{ Targeting List PKH } \\
\hline & & & & & PMT & Community & Community \\
\hline \multirow[t]{2}{*}{ Elite } & & & & & -0.027 & -0.005 & -0.049 \\
\hline & & & & & $(0.023)$ & $(0.025)$ & $(0.037)$ \\
\hline \multirow[t]{2}{*}{ Log Consumption } & & & & & $-0.197 * * *$ & $-0.210 * * *$ & $-0.209 * * *$ \\
\hline & & & & & $(0.016)$ & $(0.016)$ & $(0.016)$ \\
\hline \multirow[t]{2}{*}{ Elite Subtreatment } & & & & & & & -0.018 \\
\hline & & & & & & & $(0.025)$ \\
\hline \multirow[t]{2}{*}{ Elite $\mathrm{x}$ Elite Subtreatment } & & & & & & & $0.089^{*}$ \\
\hline & & & & & & & $(0.048)$ \\
\hline Observations & & & & & 1,814 & 1,881 & 1,881 \\
\hline Dependent Variable Mean & & & & & 0.294 & 0.313 & 0.313 \\
\hline
\end{tabular}

Notes: Each column shows an OLS regression of benefit receipt or benefit targeting on elite and log per capita consumption. Stratum fixed effects are included in all regressions. Standard

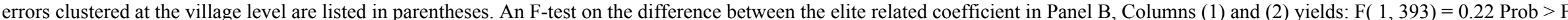
$=.6369$. The same test in Panel C yields $\mathrm{F}(1,639)=.01$ Prob $>\mathrm{F}=.9298 . \quad * * * \mathrm{p}<0.01, * * \mathrm{p}<0.05, * \mathrm{p}<0.1$ 
Table 3: Elite Capture by Formal Versus Informal Elites

\begin{tabular}{|c|c|c|c|c|c|c|c|}
\hline & $(1)$ & $(2)$ & (3) & (4) & $(5)$ & $(6)$ & $(7)$ \\
\hline & \multicolumn{7}{|c|}{ Panel A: Government Transfer Programs - Formal Elites } \\
\hline & BLT 05 & BLT 08 & Jamkesmas & Raskin & PPLS 1 & PPLS 2 & PPLS 3 \\
\hline \multirow[t]{2}{*}{ Elite } & $0.049 * * *$ & $0.047 * * *$ & $0.082 * * *$ & $0.032 * *$ & 0.026 & -0.011 & -0.008 \\
\hline & $(0.018)$ & $(0.018)$ & $(0.018)$ & $(0.014)$ & $(0.017)$ & $(0.015)$ & $(0.010)$ \\
\hline Observations & 3,985 & 3,985 & 3,996 & 3,996 & 3,996 & 3,996 & 3,996 \\
\hline \multirow[t]{3}{*}{ Dependent Variable Mean } & 0.362 & 0.387 & 0.425 & 0.751 & 0.359 & 0.262 & 0.102 \\
\hline & \multicolumn{7}{|c|}{$\begin{array}{l}\text { Panel B: Government Transfer Programs - Informal Elites } \\
\text { Receives Benefits }\end{array}$} \\
\hline & BLT 05 & BLT 08 & Jamkesmas & Raskin & PPLS 1 & PPLS 2 & PPLS 3 \\
\hline \multirow[t]{2}{*}{ Elite } & $-0.069 * * *$ & $-0.066 * * *$ & $-0.064 * * *$ & $-0.061 * * *$ & -0.017 & $-0.030 *$ & -0.017 \\
\hline & $(0.020)$ & $(0.021)$ & $(0.023)$ & $(0.017)$ & $(0.021)$ & $(0.018)$ & $(0.012)$ \\
\hline Observations & 3,985 & 3,985 & 3,996 & 3,996 & 3,996 & 3,996 & 3,996 \\
\hline \multirow[t]{4}{*}{ Dependent Variable Mean } & 0.362 & 0.387 & 0.425 & 0.751 & 0.359 & 0.262 & 0.102 \\
\hline & \multicolumn{7}{|c|}{ Panel C: PKH Experiment - Formal Elites } \\
\hline & \multicolumn{3}{|c|}{ Receives PKH } & & \multicolumn{3}{|c|}{ Targeting Lists } \\
\hline & PMT & Community & Community & & PMT & Community & Community \\
\hline \multirow[t]{2}{*}{ Elite } & $-0.034 * *$ & $-0.042 * * *$ & -0.021 & & $-0.017 *$ & -0.018 & -0.017 \\
\hline & $(0.015)$ & $(0.015)$ & $(0.023)$ & & $(0.009)$ & $(0.012)$ & $(0.018)$ \\
\hline \multirow[t]{2}{*}{ Elite x Elite Subtreatment } & & & -0.042 & & & & -0.003 \\
\hline & & & $(0.031)$ & & & & $(0.024)$ \\
\hline Observations & 1,863 & 1,936 & 1,936 & & 1,996 & 2,000 & 2,000 \\
\hline \multirow[t]{4}{*}{ Dependent Variable Mean } & 0.110 & 0.142 & 0.142 & & 0.0431 & 0.0770 & 0.0770 \\
\hline & \multicolumn{6}{|c|}{ Panel D: PKH Experiment — Informal Elites } & \\
\hline & \multicolumn{3}{|c|}{ Receives PKH } & & \multicolumn{3}{|c|}{ Targeting Lists } \\
\hline & PMT & Community & Community & & PMT & Community & Community \\
\hline \multirow[t]{2}{*}{ Elite } & $-0.033^{*}$ & -0.020 & -0.018 & & -0.011 & $-0.040 * * *$ & $-0.051 * *$ \\
\hline & $(0.017)$ & $(0.018)$ & $(0.026)$ & & $(0.011)$ & $(0.014)$ & $(0.021)$ \\
\hline Elite $\mathrm{x}$ Elite Subtreatment & & & -0.004 & & & & 0.022 \\
\hline Observations & 1,863 & 1,936 & $\begin{array}{c}(0.038) \\
1,936\end{array}$ & & 1,996 & 2,000 & $\begin{array}{c}(0.029) \\
2,000\end{array}$ \\
\hline Dependent Variable Mean & 0.110 & 0.142 & 0.142 & & 0.0431 & 0.0770 & 0.0770 \\
\hline
\end{tabular}

Notes: Each column shows an OLS regression of benefit receipt or benefit targeting on elite status and log per capita consumption. Stratum fixed effects are included in all regressions.

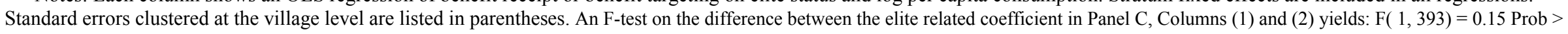
$\mathrm{F}=.7023$. The same test in Panel D yields: $\mathrm{F}(1,393)=0.29$ Prob $>\mathrm{F}=.5931 . \quad * * * \mathrm{p}<0.01,{ }^{* *} \mathrm{p}<0.05,{ }^{*} \mathrm{p}<0.1$ 
Table 4: Under/Over Quotas and Elite Capture

\begin{tabular}{|c|c|c|c|c|}
\hline & \multicolumn{4}{|c|}{ Beneficiaries } \\
\hline & $(1)$ & $(2)$ & (3) & $(4)$ \\
\hline \multicolumn{5}{|c|}{ Panel A: High Cut-Off } \\
\hline & BLT 05 & BLT 08 & Jamkesmas & Raskin \\
\hline \multirow[t]{2}{*}{ Elite } & -0.017 & -0.009 & 0.010 & -0.010 \\
\hline & $(0.018)$ & $(0.019)$ & $(0.019)$ & $(0.015)$ \\
\hline \multirow[t]{2}{*}{ Log consumption } & $-0.195 * * *$ & $-0.201 * * *$ & $-0.186 * * *$ & $-0.204 * * *$ \\
\hline & $(0.014)$ & $(0.014)$ & $(0.014)$ & $(0.014)$ \\
\hline \multirow[t]{2}{*}{ Program slots $>150 \%$ of quota } & -0.014 & 0.022 & 0.028 & -0.008 \\
\hline & $(0.027)$ & $(0.027)$ & $(0.029)$ & $(0.029)$ \\
\hline \multirow[t]{2}{*}{ Elite $*$ slots $>150 \%$ of quota } & $0.085 * *$ & 0.064 & $0.079 * *$ & 0.018 \\
\hline & $(0.039)$ & $(0.042)$ & $(0.039)$ & $(0.030)$ \\
\hline Observations & 3,982 & 3,982 & 3,993 & 3,993 \\
\hline \multirow[t]{3}{*}{ Dependent Variable Mean } & 0.361 & 0.387 & 0.425 & 0.750 \\
\hline & Panel B: & nder Cut-Of & & \\
\hline & BLT 05 & BLT 08 & Jamkesmas & Raskin \\
\hline \multirow[t]{2}{*}{ Elite } & -0.034 & -0.012 & -0.003 & -0.023 \\
\hline & $(0.022)$ & $(0.021)$ & $(0.023)$ & $(0.020)$ \\
\hline \multirow[t]{2}{*}{ Log consumption } & $-0.195 * * *$ & $-0.201 * * *$ & $-0.186 * * *$ & $-0.204 * * *$ \\
\hline & $(0.014)$ & $(0.014)$ & $(0.014)$ & $(0.014)$ \\
\hline \multirow[t]{2}{*}{ Program slots over quota } & 0.032 & 0.036 & 0.015 & 0.005 \\
\hline & $(0.023)$ & $(0.023)$ & $(0.025)$ & $(0.026)$ \\
\hline \multirow[t]{2}{*}{ Elite $*$ slots over quota } & $0.065 * *$ & 0.032 & $0.058 *$ & 0.031 \\
\hline & $(0.032)$ & $(0.032)$ & $(0.033)$ & $(0.026)$ \\
\hline Observations & 3,982 & 3,982 & 3,993 & 3,993 \\
\hline Dependent Variable Mean & 0.361 & 0.387 & 0.425 & 0.750 \\
\hline
\end{tabular}

Notes: Each column shows an OLS regression of benefit receipt on elite status, log per capita consumption, a dummy for the level of program slots in the village relative to quota, and an

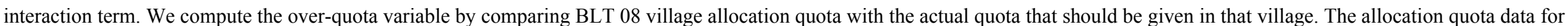

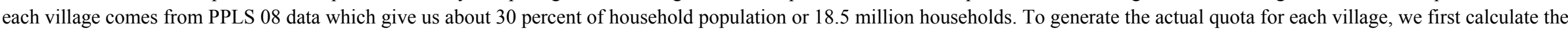

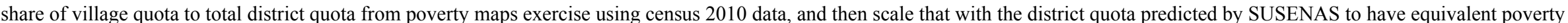

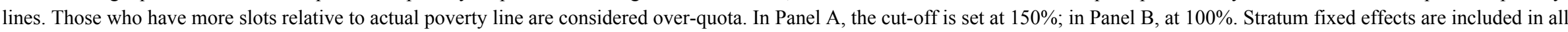
regressions. Standard errors clustered at the village level are listed in parentheses. ${ }^{* *} \mathrm{p}<0.01, * * \mathrm{p}<0.05, * \mathrm{p}<0.1$ 
Table 5A: Do Elections Constrain Elites?: Government Transfer Programs

\begin{tabular}{|c|c|c|c|c|c|c|c|}
\hline & $(1)$ & $(2)$ & $(3)$ & $(4)$ & $(5)$ & $(6)$ & $(7)$ \\
\hline & \multicolumn{7}{|c|}{ Panel A: Government Transfer Programs } \\
\hline & & Rec & enefits & & & rgeting L & \\
\hline & BLT 05 & BLT 08 & Jamkesmas & Raskin & PPLS 1 & PPLS 2 & PPLS 3 \\
\hline \multirow[t]{2}{*}{ Elite $\mathrm{x}$ Elected } & 0.008 & 0.017 & $0.146 * * *$ & $0.074 * *$ & 0.037 & 0.028 & 0.017 \\
\hline & $(0.045)$ & $(0.047)$ & $(0.051)$ & $(0.035)$ & $(0.047)$ & $(0.044)$ & $(0.026)$ \\
\hline Observations & 3,945 & 3,945 & 3,956 & 3,956 & 3,956 & 3,956 & 3,956 \\
\hline \multirow[t]{3}{*}{ Dependent Variable Mean } & 0.360 & 0.386 & 0.425 & 0.749 & 0.360 & 0.261 & 0.102 \\
\hline & \multicolumn{7}{|c|}{ Panel B: Government Transfer Programs — Formal Elites } \\
\hline & BLT 05 & BLT 08 & Jamkesmas & Raskin & PPLS 1 & PPLS 2 & PPLS 3 \\
\hline \multirow[t]{2}{*}{ Elite $\mathrm{x}$ Elected } & -0.033 & -0.023 & $0.133 * *$ & $0.080^{*}$ & 0.030 & 0.032 & 0.012 \\
\hline & $(0.053)$ & $(0.050)$ & $(0.052)$ & $(0.044)$ & $(0.048)$ & $(0.043)$ & $(0.030)$ \\
\hline Observations & 3,945 & 3,945 & 3,956 & 3,956 & 3,956 & 3,956 & 3,956 \\
\hline \multirow[t]{3}{*}{ Dependent Variable Mean } & 0.360 & 0.386 & 0.425 & 0.749 & 0.360 & 0.261 & 0.102 \\
\hline & \multicolumn{7}{|c|}{$\begin{array}{l}\text { Panel C: Government Transfer Programs - Informal Elites } \\
\text { Receives Benefits }\end{array}$} \\
\hline & BLT 05 & BLT 08 & Jamkesmas & Raskin & PPLS 1 & PPLS 2 & PPLS 3 \\
\hline \multirow[t]{2}{*}{ Elite $\mathrm{x}$ Elected } & 0.079 & 0.074 & 0.093 & 0.037 & 0.091 & 0.059 & 0.007 \\
\hline & $(0.059)$ & $(0.063)$ & $(0.071)$ & $(0.046)$ & $(0.063)$ & $(0.056)$ & $(0.038)$ \\
\hline Observations & 3,945 & 3,945 & 3,956 & 3,956 & 3,956 & 3,956 & 3,956 \\
\hline Dependent Variable Mean & 0.360 & 0.386 & 0.425 & 0.749 & 0.360 & 0.261 & 0.102 \\
\hline
\end{tabular}

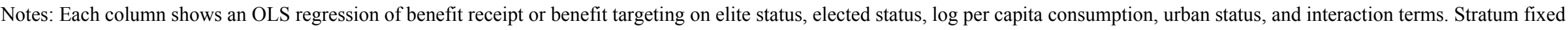
effects are included in all regressions. Standard errors clustered at the village level are listed in parentheses. $* * * \mathrm{p}<0.01, * * \mathrm{p}<0.05, * \mathrm{p}<0.1$ 
Table 5B: Do Elections Constrain Elites? Evidence from the PKH Experiment

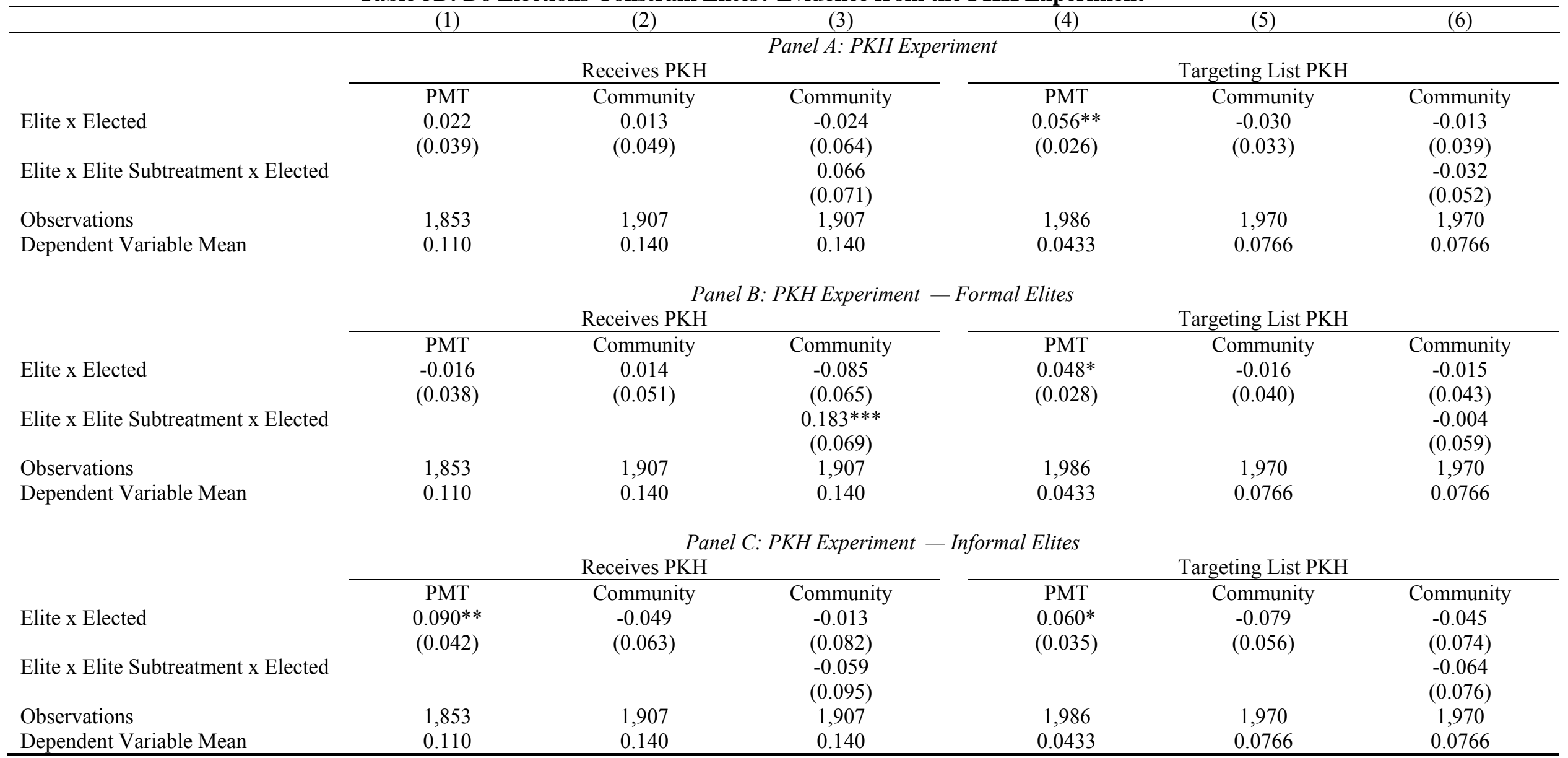

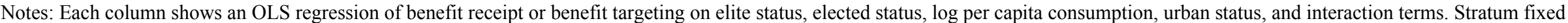
effects are included in all regressions. Standard errors clustered at the village level are listed in parentheses. $* * * \mathrm{p}<0.01, * * \mathrm{p}<0.05, * \mathrm{p}<0.1$ 
Table 6: Testing for Patronage in Community Targeting in the PKH Experiment

\begin{tabular}{|c|c|c|c|c|c|c|}
\hline & \multicolumn{2}{|c|}{ Baseline Survey } & \multicolumn{2}{|c|}{ Receives PKH } & \multicolumn{2}{|c|}{ Targeting List PKH } \\
\hline & $\begin{array}{l}\text { Leaders } \\
(1)\end{array}$ & $\begin{array}{l}\text { Non-Leaders } \\
(2)\end{array}$ & $\begin{array}{c}\text { Elite } \\
\text { Subtreatment } \\
(3) \\
\end{array}$ & $\begin{array}{c}\text { Full } \\
\text { Community } \\
(4)\end{array}$ & $\begin{array}{c}\text { Elite } \\
\text { Subtreatment } \\
(5) \\
\end{array}$ & $\begin{array}{c}\text { Full } \\
\text { Community } \\
(6)\end{array}$ \\
\hline Log per capita consumption & $\begin{array}{c}-0.170 * * * \\
(0.011)\end{array}$ & $\begin{array}{l}-0.145^{* * * *} \\
(0.008)\end{array}$ & $\begin{array}{l}-0.071 * * * \\
(0.024)\end{array}$ & $\begin{array}{c}-0.091 * * * \\
(0.025)\end{array}$ & $\begin{array}{c}-0.050 * * * \\
(0.018)\end{array}$ & $\begin{array}{c}-0.050^{* * *} \\
(0.019)\end{array}$ \\
\hline Log household size & $\begin{array}{l}-0.149 * * * \\
(0.017)\end{array}$ & $\begin{array}{c}-0.123 * * * \\
(0.012)\end{array}$ & $\begin{array}{l}0.074 * * \\
(0.031)\end{array}$ & $\begin{array}{c}0.048 \\
(0.043)\end{array}$ & $\begin{array}{c}0.028 \\
(0.024)\end{array}$ & $\begin{array}{l}-0.008 \\
(0.029)\end{array}$ \\
\hline Share of children in household & $\begin{array}{c}0.077 * * * \\
(0.029)\end{array}$ & $\begin{array}{l}0.075 * * * \\
(0.022)\end{array}$ & $\begin{array}{l}0.366^{* * *} \\
(0.071)\end{array}$ & $\begin{array}{l}0.376 * * * \\
(0.074)\end{array}$ & $\begin{array}{l}0.196 * * * \\
(0.056)\end{array}$ & $\begin{array}{c}0.111 \\
(0.068)\end{array}$ \\
\hline Elite connectedness & $\begin{array}{c}-0.034 * * * \\
(0.010)\end{array}$ & $\begin{array}{c}-0.042 * * * \\
(0.008)\end{array}$ & $\begin{array}{l}-0.046^{*} \\
(0.024)\end{array}$ & $\begin{array}{l}-0.022 \\
(0.024)\end{array}$ & $\begin{array}{l}-0.017 \\
(0.019)\end{array}$ & $\begin{array}{l}-0.014 \\
(0.019)\end{array}$ \\
\hline Connected with other households & $\begin{array}{l}-0.007 \\
(0.011)\end{array}$ & $\begin{array}{l}-0.007 \\
(0.008)\end{array}$ & $\begin{array}{c}0.037 \\
(0.027)\end{array}$ & $\begin{array}{c}0.034 \\
(0.025)\end{array}$ & $\begin{array}{c}0.028 \\
(0.019)\end{array}$ & $\begin{array}{c}0.001 \\
(0.019)\end{array}$ \\
\hline $\begin{array}{l}\text { Having family members outside the } \\
\text { village }\end{array}$ & $\begin{array}{c}-0.014 * * * \\
(0.003)\end{array}$ & $\begin{array}{c}-0.010 * * * \\
(0.003)\end{array}$ & $\begin{array}{c}0.020 \\
(0.012)\end{array}$ & $\begin{array}{c}0.001 \\
(0.009)\end{array}$ & $\begin{array}{c}0.001 \\
(0.009)\end{array}$ & $\begin{array}{c}0.005 \\
(0.008)\end{array}$ \\
\hline Participating in religious groups & $\begin{array}{l}0.000 \\
(0.009)\end{array}$ & $\begin{array}{l}-0.006 \\
(0.007)\end{array}$ & $\begin{array}{l}-0.036 \\
(0.025)\end{array}$ & $\begin{array}{l}-0.042^{*} \\
(0.025)\end{array}$ & $\begin{array}{c}-0.034 * * \\
(0.017)\end{array}$ & $\begin{array}{l}-0.023 \\
(0.016)\end{array}$ \\
\hline Participating in community projects & $\begin{array}{c}0.011 \\
(0.011)\end{array}$ & $\begin{array}{c}0.023 * * * \\
(0.008)\end{array}$ & $\begin{array}{c}0.036 \\
(0.037)\end{array}$ & $\begin{array}{l}-0.024 \\
(0.037)\end{array}$ & $\begin{array}{c}0.012 \\
(0.020)\end{array}$ & $\begin{array}{c}0.005 \\
(0.019)\end{array}$ \\
\hline Contributing money to village projects & $\begin{array}{c}-0.023 * * \\
(0.009)\end{array}$ & $\begin{array}{c}-0.026^{* * *} * \\
(0.007)\end{array}$ & $\begin{array}{l}-0.010 \\
(0.024)\end{array}$ & $\begin{array}{l}-0.021 \\
(0.026)\end{array}$ & $\begin{array}{c}0.010 \\
(0.020)\end{array}$ & $\begin{array}{l}-0.028 \\
(0.020)\end{array}$ \\
\hline Working hard & $\begin{array}{c}-0.056^{* * *} * \\
(0.003)\end{array}$ & $\begin{array}{c}-0.052 * * * \\
(0.003)\end{array}$ & $\begin{array}{c}-0.030 * * * \\
(0.007)\end{array}$ & $\begin{array}{c}-0.016^{* *} \\
(0.008)\end{array}$ & $\begin{array}{c}-0.019 * * * \\
(0.006)\end{array}$ & $\begin{array}{l}-0.009^{*} \\
(0.005)\end{array}$ \\
\hline Friendliness & $\begin{array}{l}-0.007^{*} \\
(0.003)\end{array}$ & $\begin{array}{c}-0.011^{* * *} \\
(0.003)\end{array}$ & $\begin{array}{c}0.010 \\
(0.007)\end{array}$ & $\begin{array}{l}0.014^{*} \\
(0.008)\end{array}$ & $\begin{array}{c}0.004 \\
(0.006)\end{array}$ & $\begin{array}{c}0.002 \\
(0.006)\end{array}$ \\
\hline Total savings amount & $\begin{array}{c}-0.000^{* * * *} \\
(0.000)\end{array}$ & $\begin{array}{c}-0.000 * * * \\
(0.000)\end{array}$ & $\begin{array}{c}0.000 \\
(0.000)\end{array}$ & $\begin{array}{l}-0.000 \\
(0.000)\end{array}$ & $\begin{array}{l}-0.000 \\
(0.000)\end{array}$ & $\begin{array}{c}-0.000 \\
(0.000)\end{array}$ \\
\hline Share of savings in bank & $\begin{array}{c}-0.081 * * * \\
(0.015)\end{array}$ & $\begin{array}{c}-0.088 * * * \\
(0.011)\end{array}$ & $\begin{array}{l}-0.003 \\
(0.032)\end{array}$ & $\begin{array}{c}0.023 \\
(0.038)\end{array}$ & $\begin{array}{c}0.020 \\
(0.027)\end{array}$ & $\begin{array}{l}-0.012 \\
(0.028)\end{array}$ \\
\hline Share of debt & $\begin{array}{c}-0.007 * * * \\
(0.001)\end{array}$ & $\begin{array}{c}-0.006 * * * \\
(0.001)\end{array}$ & $\begin{array}{l}-0.001 \\
(0.003)\end{array}$ & $\begin{array}{l}-0.003 \\
(0.002)\end{array}$ & $\begin{array}{l}-0.002 \\
(0.001)\end{array}$ & $\begin{array}{c}-0.004 * * * \\
(0.001)\end{array}$ \\
\hline Being ethnic minority & $\begin{array}{c}0.027^{* *} \\
(0.010)\end{array}$ & $\begin{array}{c}0.013 \\
(0.009)\end{array}$ & $\begin{array}{l}-0.001 \\
(0.036)\end{array}$ & $\begin{array}{c}0.008 \\
(0.040)\end{array}$ & $\begin{array}{c}0.022 \\
(0.022)\end{array}$ & $\begin{array}{c}-0.015 \\
(0.028)\end{array}$ \\
\hline Being religious minority & $\begin{array}{c}0.016 \\
(0.037)\end{array}$ & $\begin{array}{c}0.005 \\
(0.025)\end{array}$ & $\begin{array}{c}0.096 \\
(0.072)\end{array}$ & $\begin{array}{l}-0.026 \\
(0.050)\end{array}$ & $\begin{array}{c}0.029 \\
(0.055)\end{array}$ & $\begin{array}{c}0.034 \\
(0.052)\end{array}$ \\
\hline $\begin{array}{l}\text { Household head has elementary education } \\
\text { or less }\end{array}$ & $\begin{array}{c}0.054 * * * \\
(0.009)\end{array}$ & $\begin{array}{l}0.051 * * * \\
(0.007)\end{array}$ & $\begin{array}{l}0.042^{*} \\
(0.022)\end{array}$ & $\begin{array}{c}0.069 * * * \\
(0.022)\end{array}$ & $\begin{array}{c}0.048 * * * \\
(0.018)\end{array}$ & $\begin{array}{l}0.035^{* *} \\
(0.017)\end{array}$ \\
\hline Household head is widow & $\begin{array}{c}0.006 \\
(0.026)\end{array}$ & $\begin{array}{c}0.010 \\
(0.019)\end{array}$ & $\begin{array}{c}0.072 \\
(0.067)\end{array}$ & $\begin{array}{c}0.048 \\
(0.060)\end{array}$ & $\begin{array}{l}0.099^{*} \\
(0.056)\end{array}$ & $\begin{array}{c}0.117 \\
(0.073)\end{array}$ \\
\hline Household head is disabled & $\begin{array}{l}0.043 * * \\
(0.017)\end{array}$ & $\begin{array}{c}0.018 \\
(0.013)\end{array}$ & $\begin{array}{c}0.022 \\
(0.046)\end{array}$ & $\begin{array}{l}0.126^{* *} \\
(0.051)\end{array}$ & $\begin{array}{c}0.036 \\
(0.038)\end{array}$ & $\begin{array}{c}0.045 \\
(0.044)\end{array}$ \\
\hline $\begin{array}{l}\text { Household experienced death of family } \\
\text { member }\end{array}$ & $\begin{array}{c}0.004 \\
(0.029)\end{array}$ & $\begin{array}{c}0.003 \\
(0.023)\end{array}$ & $\begin{array}{c}0.156 \\
(0.108)\end{array}$ & $\begin{array}{l}-0.038 \\
(0.051)\end{array}$ & $\begin{array}{c}0.065 \\
(0.084)\end{array}$ & $\begin{array}{c}0.070 \\
(0.064)\end{array}$ \\
\hline Household has sick family member & $\begin{array}{c}0.020 \\
(0.012)\end{array}$ & $\begin{array}{l}0.017^{*} \\
(0.010)\end{array}$ & $\begin{array}{c}0.032 \\
(0.032)\end{array}$ & $\begin{array}{l}-0.034 \\
(0.031)\end{array}$ & $\begin{array}{c}0.019 \\
(0.027)\end{array}$ & $\begin{array}{c}0.007 \\
(0.028)\end{array}$ \\
\hline Household experienced income shock & $\begin{array}{l}0.005 \\
(0.009)\end{array}$ & $\begin{array}{c}0.011 \\
(0.008)\end{array}$ & $\begin{array}{l}0.005 \\
(0.026)\end{array}$ & $\begin{array}{c}0.089 * * * \\
(0.025)\end{array}$ & $\begin{array}{l}-0.004 \\
(0.020)\end{array}$ & $\begin{array}{c}0.011 \\
(0.020)\end{array}$ \\
\hline Tobacco and/or alcohol consumption & $\begin{array}{c}0.083 * * * \\
(0.027)\end{array}$ & $\begin{array}{c}0.071 * * * \\
(0.022)\end{array}$ & $\begin{array}{c}0.018 \\
(0.066)\end{array}$ & $\begin{array}{c}0.056 \\
(0.049)\end{array}$ & $\begin{array}{l}-0.015 \\
(0.055)\end{array}$ & $\begin{array}{c}0.071 \\
(0.045)\end{array}$ \\
\hline $\begin{array}{l}\text { Observations } \\
\text { Dependent Variable Mean }\end{array}$ & $\begin{array}{l}3,773 \\
0.502\end{array}$ & $\begin{array}{l}3,984 \\
0.547\end{array}$ & $\begin{array}{c}968 \\
0.138\end{array}$ & $\begin{array}{c}967 \\
0.146\end{array}$ & $\begin{array}{c}1,000 \\
0.0740\end{array}$ & $\begin{array}{c}999 \\
0.0801\end{array}$ \\
\hline
\end{tabular}

Notes: Columns 1 and 2 show OLS regressions of social ranking on a variety of regressors. Columns 3-6 show OLS regressions of benefit receipt on those regressors. Standard errors clustered at the village level are listed in parentheses. Stratum fixed effects are included in all regressions. Ftests between columns: Column 1 vs $2: F(2,399)=1.72$ Prob $>F=0.0217,3$ vs $4: F(23,199)=1.30$ Prob $>F=0.17175$ vs 6: $F(23,199)=0.76$ Prob $>\mathrm{F}=0.7718 . \quad * * * \mathrm{p}<0.01, * * \mathrm{p}<0.05, * \mathrm{p}<0.1$ 
Table 7: Simulated Social Welfare under Different Levels of Capture

\begin{tabular}{|c|c|c|c|c|c|}
\hline & $\begin{array}{c}(1) \\
\text { PKH Experiment }\end{array}$ & $\begin{array}{c}(2) \\
\text { BLT05 }\end{array}$ & $\begin{array}{c}(3) \\
\text { BLT08 }\end{array}$ & $\begin{array}{c}(4) \\
\text { Jamkesmas }\end{array}$ & $\begin{array}{c}(5) \\
\text { Raskin }\end{array}$ \\
\hline \multicolumn{6}{|c|}{ Panel A: Elites } \\
\hline \multicolumn{6}{|l|}{ Utility... } \\
\hline Without program & -6.689 & -6.689 & -6.689 & -6.689 & -6.689 \\
\hline With Elite on & -6.600 & -6.296 & -6.268 & -6.664 & -6.442 \\
\hline With Elite off & -6.601 & -6.296 & -6.266 & -6.664 & -6.441 \\
\hline Under perfect PMT-targeting & -6.550 & -6.171 & -6.148 & -6.657 & -6.424 \\
\hline Under perfect consumption targeting & -6.354 & -6.005 & -5.991 & -6.648 & -6.409 \\
\hline \multicolumn{6}{|l|}{ Share of possible utility gain... } \\
\hline With Elite on & $26.51 \%$ & $57.40 \%$ & $60.23 \%$ & $61.82 \%$ & $88.34 \%$ \\
\hline With Elite off & $26.28 \%$ & $57.39 \%$ & $60.50 \%$ & $62.08 \%$ & $88.54 \%$ \\
\hline Under perfect PMT-targeting & $41.37 \%$ & $75.73 \%$ & $77.39 \%$ & $78.40 \%$ & $94.89 \%$ \\
\hline \multicolumn{6}{|c|}{ Panel B: Formal Elites } \\
\hline \multicolumn{6}{|l|}{ Utility... } \\
\hline Without program & -6.689 & -6.689 & -6.689 & -6.689 & -6.689 \\
\hline With Elite on & -6.600 & -6.296 & -6.269 & -6.664 & -6.442 \\
\hline With Elite off & -6.600 & -6.292 & -6.263 & -6.663 & -6.441 \\
\hline Under perfect PMT-targeting & -6.550 & -6.171 & -6.149 & -6.657 & -6.424 \\
\hline Under perfect consumption targeting & -6.354 & -6.005 & -5.991 & -6.648 & -6.409 \\
\hline \multicolumn{6}{|l|}{ Share of possible utility gain... } \\
\hline With Elite on & $26.58 \%$ & $57.37 \%$ & $60.20 \%$ & $61.75 \%$ & $88.33 \%$ \\
\hline With Elite off & $26.35 \%$ & $57.98 \%$ & $60.98 \%$ & $62.93 \%$ & $88.79 \%$ \\
\hline Under perfect PMT-targeting & $41.37 \%$ & $75.73 \%$ & $77.26 \%$ & $78.38 \%$ & $94.89 \%$ \\
\hline \multicolumn{6}{|c|}{ Panel C: Informal Elites } \\
\hline \multicolumn{6}{|l|}{ Utility... } \\
\hline Without program & -6.689 & -6.689 & -6.689 & -6.689 & -6.689 \\
\hline With Elite on & -6.600 & -6.297 & -6.269 & -6.664 & -6.442 \\
\hline With Elite off & -6.600 & -6.299 & -6.271 & -6.664 & -6.443 \\
\hline Under perfect PMT-targeting & -6.550 & -6.171 & -6.149 & -6.657 & -6.424 \\
\hline Under perfect consumption targeting & -6.354 & -6.005 & -5.991 & -6.648 & -6.409 \\
\hline \multicolumn{6}{|l|}{ Share of possible utility gain... } \\
\hline With Elite on & $26.55 \%$ & $57.32 \%$ & $60.17 \%$ & $61.67 \%$ & $88.29 \%$ \\
\hline With Elite off & $26.49 \%$ & $56.94 \%$ & $59.87 \%$ & $61.10 \%$ & $88.02 \%$ \\
\hline Under perfect PMT-targeting & $41.37 \%$ & $75.73 \%$ & $77.26 \%$ & $78.40 \%$ & $94.89 \%$ \\
\hline
\end{tabular}

Notes: Utility is calculated as a monotonically increasing function of $\log$ per capita consumption, $\mathrm{u}=-\left(\log (\mathrm{x})^{\wedge}-2\right) / 2$ (note that, under this formula, all $\mathrm{utility}$ is defined to be negative).

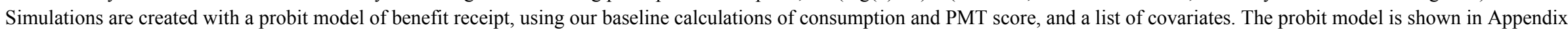
Table 12. 
Figure 1: Experimental Design

\begin{tabular}{|c|c|c|c|c|}
\hline & \multicolumn{2}{|c|}{ Main Treatments } \\
\hline & & & Community Input & PMT (Control) \\
\hline \multirow{5}{*}{$\begin{array}{l}\text { Community } \\
\text { Input Sub- } \\
\text { treatments }\end{array}$} & \multirow{2}{*}{$\begin{array}{l}\text { Full Community } \\
\text { Meeting }\end{array}$} & Add & 50 & \\
\hline & & Add \& Replace & 50 & \\
\hline & \multirow[t]{2}{*}{ Elite Meeting } & Add & 50 & \\
\hline & & Add \& Replace & 50 & \\
\hline & \multicolumn{2}{|r|}{ TOTAL } & 200 & 200 \\
\hline
\end{tabular}


Appendix Table 1: Do Elite Capture Targeted Programs? (4 votes for Elite Status rather than two)

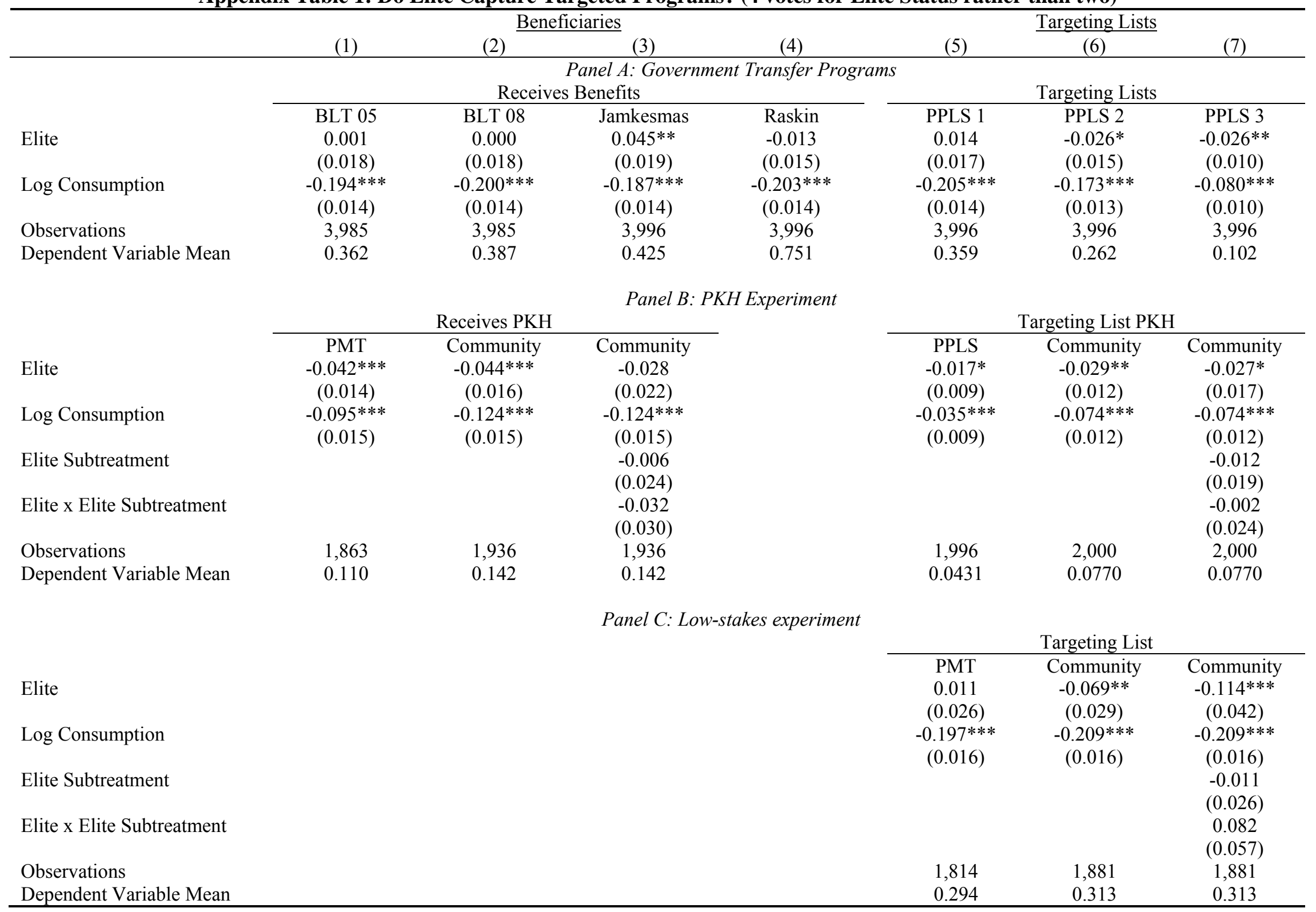

Notes: Each column shows an OLS regression of benefit receipt or benefit targeting on elite status and log per capita consumption. Stratum fixed effects are included in all regressions. Standard errors clustered at the village level are listed in parentheses. $\quad * * * \mathrm{p}<0.01, * * \mathrm{p}<0.05, * \mathrm{p}<0.1$ 
Appendix Table 2: Do Elite Capture Targeted Programs? Without Controls for Consumption

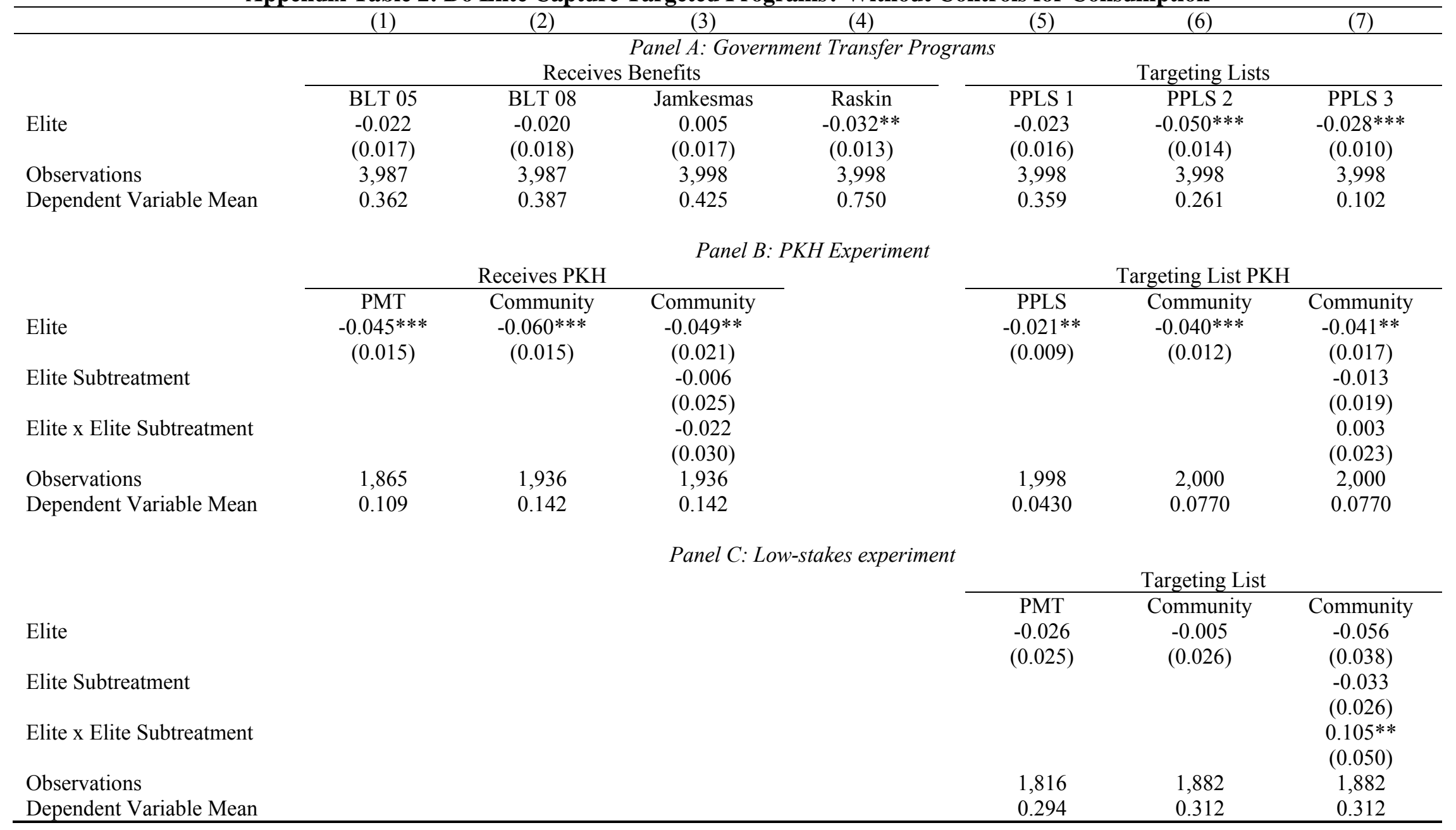

Notes: Each column shows an OLS regression of benefit receipt or benefit targeting on elite status. Stratum fixed effects are included in all regressions Standard errors clustered at the village level are listed in parentheses. $\quad{ }^{* * *} \mathrm{p}<0.01,{ }^{* *} \mathrm{p}<0.05,{ }^{*} \mathrm{p}<0.1$ 
Appendix Table 3: Do Elites Capture Targeted Programs? (Social Connection with Elites)

\begin{tabular}{|c|c|c|c|c|c|c|c|}
\hline & $(1)$ & $(2)$ & (3) & (4) & $(5)$ & (6) & $(7)$ \\
\hline & \multicolumn{6}{|c|}{ Panel A: Government Transfer Programs } & \\
\hline $\begin{array}{l}\text { Social/community groups } \\
\text { with RT Head }\end{array}$ & $\begin{array}{c}\text { BLT } 05 \\
-0.016 \\
(0.016)\end{array}$ & $\begin{array}{c}\text { BLT } 08 \\
-0.017 \\
(0.015)\end{array}$ & $\begin{array}{c}\text { Jamkesmas } \\
-0.021 \\
(0.016)\end{array}$ & $\begin{array}{c}\text { Raskin } \\
-0.026 * \\
(0.016)\end{array}$ & $\begin{array}{c}\text { PPLS 1 } \\
0.008 \\
(0.015)\end{array}$ & $\begin{array}{c}\text { PPLS } 2 \\
0.005 \\
(0.015)\end{array}$ & $\begin{array}{c}\text { PPLS } 3 \\
-0.000 \\
(0.009)\end{array}$ \\
\hline \multirow[t]{2}{*}{ Dependent Variable Mean } & $\begin{array}{l}3,588 \\
0.358\end{array}$ & $\begin{array}{l}3,588 \\
0.387\end{array}$ & $\begin{array}{l}3,596 \\
0.417\end{array}$ & $\begin{array}{l}3,596 \\
0.753\end{array}$ & $\begin{array}{l}3,596 \\
0.359\end{array}$ & $\begin{array}{l}3,596 \\
0.266\end{array}$ & $\begin{array}{l}3,596 \\
0.105\end{array}$ \\
\hline & \multicolumn{6}{|c|}{ Panel B: PKH Experiment } & \\
\hline $\begin{array}{l}\text { Social/community groups } \\
\text { with RT Head }\end{array}$ & $\begin{array}{c}\text { PMT } \\
-0.001 \\
(0.013)\end{array}$ & $\begin{array}{c}\text { Community } \\
-0.003 \\
(0.017)\end{array}$ & & & $\begin{array}{c}\text { PMT } \\
-0.001 \\
(0.005)\end{array}$ & $\begin{array}{c}\text { Community } \\
0.014 \\
(0.016)\end{array}$ & \\
\hline $\begin{array}{l}\text { Observations } \\
\text { Dependent Variable Mean }\end{array}$ & $\begin{array}{l}1,670 \\
0.114\end{array}$ & $\begin{array}{l}1,739 \\
0.151\end{array}$ & & & $\begin{array}{c}1,796 \\
0.0451\end{array}$ & $\begin{array}{c}1,800 \\
0.0817\end{array}$ & \\
\hline
\end{tabular}

Notes: Each column shows an OLS regression of benefit receipt or benefit targeting on elite status, log consumption per capita, and number of social/community groups household is a

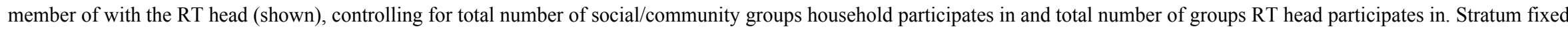
effects are included in all regressions Standard errors clustered at the village level are listed in parentheses. $\quad * * * \mathrm{p}<0.01, * * \mathrm{p}<0.05, * \mathrm{p}<0.1$ 
Appendix Table 4: Do Elite Capture Targeted Programs? With Control Variables

\begin{tabular}{|c|c|c|c|c|c|c|c|}
\hline & (1) & (2) & (3) & (4) & $(5)$ & (6) & (7) \\
\hline & \multicolumn{7}{|c|}{ Panel A: Government Transfer Programs } \\
\hline & \multicolumn{4}{|c|}{ Receives Benefits } & \multicolumn{3}{|c|}{ Targeting Lists } \\
\hline & BLT 05 & BLT 08 & Jamkesmas & Raskin & PPLS 1 & PPLS 2 & PPLS 3 \\
\hline \multirow[t]{2}{*}{ Elite } & -0.003 & 0.012 & 0.014 & -0.007 & 0.006 & -0.020 & $-0.018 *$ \\
\hline & $(0.017)$ & $(0.018)$ & $(0.018)$ & $(0.013)$ & $(0.017)$ & $(0.014)$ & $(0.010)$ \\
\hline \multirow[t]{2}{*}{ Log Consumption } & $-0.117 * * *$ & $-0.126 * * *$ & $-0.136 * * *$ & $-0.160 * * *$ & $-0.137 * * *$ & $-0.111 * * *$ & $-0.041 * * *$ \\
\hline & $(0.017)$ & $(0.016)$ & $(0.016)$ & $(0.015)$ & $(0.016)$ & $(0.014)$ & $(0.010)$ \\
\hline Observations & 3,981 & 3,981 & 3,992 & 3,992 & 3,992 & 3,992 & 3,992 \\
\hline \multirow[t]{4}{*}{ Dependent Variable Mean } & 0.362 & 0.388 & 0.425 & 0.751 & 0.359 & 0.262 & 0.102 \\
\hline & \multicolumn{7}{|c|}{ Panel B: PKH Experiment } \\
\hline & & Receives PKH & & & & rgeting List $\mathrm{P}$ & \\
\hline & PMT & Community & Community & & PMT & Community & Community \\
\hline \multirow[t]{2}{*}{ Elite } & -0.004 & $-0.039 * *$ & -0.029 & & -0.004 & -0.021 & -0.020 \\
\hline & $(0.015)$ & $(0.016)$ & $(0.021)$ & & $(0.009)$ & $(0.013)$ & $(0.017)$ \\
\hline \multirow[t]{2}{*}{ Log Consumption } & $-0.046^{* * *}$ & $-0.077 * * *$ & $-0.077 * * *$ & & -0.005 & $-0.051 * * *$ & $-0.050 * * *$ \\
\hline & $(0.015)$ & $(0.016)$ & $(0.016)$ & & $(0.009)$ & $(0.013)$ & $(0.013)$ \\
\hline \multirow[t]{2}{*}{ Elite Subtreatment } & & & -0.007 & & & & -0.012 \\
\hline & & & $(0.022)$ & & & & $(0.018)$ \\
\hline \multirow[t]{2}{*}{ Elite x Elite Subtreatment } & & & -0.021 & & & & -0.000 \\
\hline & & & $(0.027)$ & & & & $(0.022)$ \\
\hline Observations & 1,860 & 1,935 & 1,935 & & 1,993 & 1,999 & 1,999 \\
\hline \multirow[t]{4}{*}{ Dependent Variable Mean } & 0.110 & 0.142 & 0.142 & & 0.0432 & 0.0770 & 0.0770 \\
\hline & & & Panel C: & takes expert & & & \\
\hline & & & & & \multicolumn{3}{|c|}{ Targeting List } \\
\hline & & & & & PMT & Community & Community \\
\hline \multirow[t]{2}{*}{ Elite } & & & & & -0.032 & -0.006 & -0.031 \\
\hline & & & & & $(0.024)$ & $(0.025)$ & $(0.036)$ \\
\hline \multirow[t]{2}{*}{ Log Consumption } & & & & & $-0.123 * * *$ & $-0.229 * * *$ & $-0.230 * * *$ \\
\hline & & & & & $(0.020)$ & $(0.019)$ & $(0.019)$ \\
\hline \multirow[t]{2}{*}{ Elite Subtreatment } & & & & & & & -0.005 \\
\hline & & & & & & & $(0.025)$ \\
\hline Elite $\mathrm{x}$ Elite Subtreatment & & & & & & & 0.054 \\
\hline Observations & & & & & 1,814 & 1,876 & $\begin{array}{c}(0.046) \\
1,876\end{array}$ \\
\hline Dependent Variable Mean & & & & & 0.294 & 0.312 & 0.312 \\
\hline
\end{tabular}

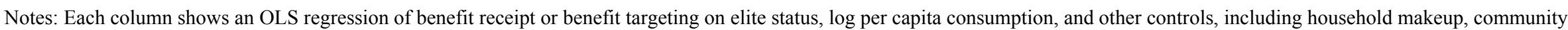

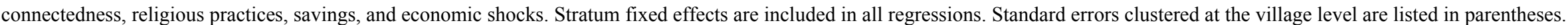
$* * * \mathrm{p}<0.01, * * \mathrm{p}<0.05, * \mathrm{p}<0.1$ 


\section{Appendix Table 5: Do Elites Capture Targeted Programs? Robustness to Village Restrictions}

\begin{tabular}{lccc}
\hline & \multicolumn{3}{c}{ Receives PKH } \\
\cline { 2 - 4 } & $\begin{array}{c}\text { PMT } \\
(1)\end{array}$ & $\begin{array}{c}\text { Community } \\
(2)\end{array}$ & $\begin{array}{c}\text { Community } \\
(3)\end{array}$ \\
& & & \\
Elite & & & \\
& & & \\
Panel A: Drop all in kecamatans & with & $>=1$ & village dropped \\
& $-0.027^{*}$ & $-0.040^{* *}$ & -0.034 \\
Elite Subtreatment & $(0.015)$ & $(0.016)$ & $(0.022)$ \\
& $-0.108^{* * *}$ & $-0.121^{* * *}$ & $-0.121^{* * *}$ \\
Elite x Elite Subtreatment & $(0.016)$ & $(0.015)$ & $(0.015)$ \\
& & & -0.017 \\
Observations & & & $(0.025)$ \\
Dependent Variable Mean & & & -0.012 \\
& 1,714 & 1,752 & $(0.031)$ \\
& 0.113 & 0.142 & 0.142
\end{tabular}

Panel B: Drop all in kecamatans with $>=10 \%$ of villages dropped

$\begin{array}{lccc}\text { Elite } & -0.027^{*} & -0.042^{* * *} & -0.031 \\ & (0.015) & (0.016) & (0.022) \\ \text { Log Consumption } & -0.108^{* * *} & -0.120^{* * *} & -0.121^{* * *} \\ & (0.016) & (0.015) & (0.015) \\ \text { Elite Subtreatment } & & & -0.010 \\ & & & (0.025) \\ \text { Elite x Elite Subtreatment } & & & -0.023 \\ & 1,744 & 1,790 & (0.031) \\ \text { Observations } & 0.111 & 0.142 & 0.790 \\ \text { Dependent Variable Mean } & & & \end{array}$

Elite

Panel C: Drop all villages dropped in new study

Log Consumption

Elite Subtreatment

Elite x Elite Subtreatment

Observations

Dependent Variable Mean

$$
\begin{gathered}
-0.032 * * \\
(0.015)
\end{gathered}
$$

$-0.097 * * *$

(0.015)

$$
\begin{gathered}
-0.041^{* * *} \\
(0.015) \\
-0.125 * * *
\end{gathered}
$$

(0.015)
$-0.026$

(0.021)

$-0.126^{* * *}$

(0.015)

$-0.001$

$(0.025)$

$-0.029$

$(0.029)$

1,869

0.141

Panel D: Drop all in kecamatans with $>=50 \%$ villages dropped, and those in new study

$\begin{array}{lll}1,834 & 1,869 & 1,869 \\ 0.111 & 0.141 & 0.141\end{array}$

Elite

Log Consumption

$-0.032 * *$

$(0.015)$

$-0.097 * * *$

$(0.015)$

Elite Subtreatment

Elite x Elite Subtreatment

Observations

1,834

0.111

Dependent Variable Mean
$-0.041^{* * *}$

(0.015)

$-0.125^{* * *}$

(0.015)
$-0.025$

(0.021)

$-0.125^{* * *}$

(0.015)

0.002

$(0.025)$

$-0.032$

(0.029)

1,849

1,849

0.142

Notes: This table test for the robustness of the results on who became a beneficiary of PKH. All regressions include stratum fixed effects and have standard errors clustered at the village level. An F-test on the difference between the elite related coefficient in Panel A, Columns (1) and (2) yields: $F(1,359)=0.38$ Prob $>F=.5384$. The same test in Panel $B$ yields: $F(1,366)=0.46$ Prob $>F=.4984$. Panel $C-F(1,383)=0.17$ Prob $>F$

$$
=.6773 \text {. Panel } \mathrm{D}-\mathrm{F}(1,381)=0.17 \text { Prob }>\mathrm{F}=.6802 . * * * \mathrm{p}<0.01, * * \mathrm{p}<0.05, * \mathrm{p}<0.1
$$


Appendix Table 6: Do Elite Capture Targeted Programs? (Household itself is elite; not including relatives)

\begin{tabular}{|c|c|c|c|c|c|c|c|}
\hline & $(1)$ & $(2)$ & (3) & $(4)$ & $(5)$ & $(6)$ & $(7)$ \\
\hline & \multicolumn{7}{|c|}{ Panel A: Government Transfer Programs Formal Elites } \\
\hline & \multicolumn{4}{|c|}{ Receives Benefits } & \multicolumn{3}{|c|}{ Targeting Lists } \\
\hline & BLT 05 & BLT 08 & Jamkesmas & Raskin & PPLS 1 & PPLS 2 & PPLS 3 \\
\hline \multirow[t]{2}{*}{ Elite } & $0.065 * * *$ & $0.040 *$ & $0.111 * * *$ & 0.000 & $0.045 * *$ & -0.006 & -0.010 \\
\hline & $(0.022)$ & $(0.021)$ & $(0.022)$ & $(0.019)$ & $(0.022)$ & $(0.019)$ & $(0.013)$ \\
\hline Observations & 3,985 & 3,985 & 3,996 & 3,996 & 3,996 & 3,996 & 3,996 \\
\hline \multirow[t]{4}{*}{ Dependent Variable Mean } & 0.362 & 0.387 & 0.425 & 0.751 & 0.359 & 0.262 & 0.102 \\
\hline & \multicolumn{7}{|c|}{ Panel B: Government Transfer Programs Informal Elites } \\
\hline & \multicolumn{4}{|c|}{ Receives Benefits } & \multicolumn{3}{|c|}{ Targeting Lists } \\
\hline & BLT 05 & BLT 08 & Jamkesmas & Raskin & PPLS 1 & PPLS 2 & PPLS 3 \\
\hline \multirow[t]{2}{*}{ Elite } & $-0.138 * * *$ & $-0.118 * * *$ & $-0.086 * * *$ & $-0.151 * * *$ & -0.045 & -0.019 & -0.009 \\
\hline & $(0.024)$ & $(0.025)$ & $(0.028)$ & $(0.026)$ & $(0.028)$ & $(0.024)$ & $(0.017)$ \\
\hline Observations & 3,985 & 3,985 & 3,996 & 3,996 & 3,996 & 3,996 & 3,996 \\
\hline \multirow[t]{4}{*}{ Dependent Variable Mean } & 0.362 & 0.387 & 0.425 & 0.751 & 0.359 & 0.262 & 0.102 \\
\hline & \multicolumn{6}{|c|}{ Panel C: PKH Experiment Formal Elites } & \\
\hline & \multicolumn{3}{|c|}{ Receives PKH } & & \multicolumn{3}{|c|}{ Targeting List PKH } \\
\hline & PMT & Community & Community & & PMT & Community & Community \\
\hline \multirow[t]{2}{*}{ Elite } & -0.019 & $-0.054 * * *$ & $-0.060 * *$ & & -0.010 & -0.022 & -0.016 \\
\hline & $(0.017)$ & $(0.018)$ & $(0.024)$ & & $(0.010)$ & $(0.015)$ & $(0.025)$ \\
\hline \multirow[t]{2}{*}{ Elite $x$ Elite Subtreatment } & & & 0.012 & & & & -0.012 \\
\hline & & & $(0.035)$ & & & & $(0.031)$ \\
\hline Observations & 1,863 & 1,936 & 1,936 & & 1,996 & 2,000 & 2,000 \\
\hline \multirow[t]{4}{*}{ Dependent Variable Mean } & 0.110 & 0.142 & 0.142 & & 0.0431 & 0.0770 & 0.0770 \\
\hline & \multicolumn{7}{|c|}{ Panel D: PKH Experiment Informal Elites } \\
\hline & \multicolumn{3}{|c|}{ Receives PKH } & & \multicolumn{3}{|c|}{ Targeting List PKH } \\
\hline & PMT & Community & Community & & PMT & Community & Community \\
\hline Elite & $-0.046 * *$ & -0.010 & -0.021 & & -0.003 & $-0.032 *$ & $-0.043 * *$ \\
\hline & $(0.023)$ & $(0.028)$ & $(0.041)$ & & $(0.016)$ & $(0.018)$ & $(0.018)$ \\
\hline Elite $x$ Elite Subtreatment & & & 0.023 & & & & 0.021 \\
\hline & & & $(0.056)$ & & & & $(0.034)$ \\
\hline Observations & 1,863 & 1,936 & 1,936 & & 1,996 & 2,000 & 2,000 \\
\hline Dependent Variable Mean & 0.110 & 0.142 & 0.142 & & 0.0431 & 0.0770 & 0.0770 \\
\hline
\end{tabular}

Notes: Each column shows an OLS regression of benefit receipt or benefit targeting on elite status (leader status) and log per capita consumption (not shown). Stratum fixed effects are included in all regressions. Standard errors clustered at the village level are listed in parentheses. $\quad * * * \mathrm{p}<0.01, * * \mathrm{p}<0.05, * \mathrm{p}<0.1$ 
Appendix Table 7: Formal Versus Informal Elites (Including Control Variables)

\begin{tabular}{|c|c|c|c|c|c|c|c|}
\hline & $(1)$ & $(2)$ & (3) & $(4)$ & $(5)$ & $(6)$ & $(7)$ \\
\hline & \multicolumn{7}{|c|}{ Panel A: Government Transfer Programs - Formal Elites } \\
\hline & BLT 05 & BLT 08 & Jamkesmas & Raskin & PPLS 1 & PPLS 2 & PPLS 3 \\
\hline \multirow[t]{2}{*}{ Elite } & $0.043 * *$ & $0.052 * * *$ & $0.069 * * *$ & $0.025^{*}$ & 0.023 & -0.004 & -0.006 \\
\hline & $(0.019)$ & $(0.019)$ & $(0.019)$ & $(0.014)$ & $(0.018)$ & $(0.015)$ & $(0.011)$ \\
\hline Observations & 3,981 & 3,981 & 3,992 & 3,992 & 3,992 & 3,992 & 3,992 \\
\hline \multirow[t]{3}{*}{ Dependent Variable Mean } & 0.362 & 0.388 & 0.425 & 0.751 & 0.359 & 0.262 & 0.102 \\
\hline & \multicolumn{7}{|c|}{$\begin{array}{l}\text { Panel B: Government Transfer Programs - Informal Elites } \\
\text { Receives Benefits }\end{array}$} \\
\hline & BLT 05 & BLT 08 & Jamkesmas & Raskin & PPLS 1 & PPLS 2 & PPLS 3 \\
\hline \multirow[t]{2}{*}{ Elite } & $-0.061 * * *$ & $-0.051 * *$ & $-0.070 * * *$ & $-0.047 * * *$ & -0.001 & -0.011 & -0.013 \\
\hline & $(0.021)$ & $(0.020)$ & $(0.023)$ & $(0.017)$ & $(0.021)$ & $(0.018)$ & $(0.012)$ \\
\hline Observations & 3,981 & 3,981 & 3,992 & 3,992 & 3,992 & 3,992 & 3,992 \\
\hline \multirow[t]{4}{*}{ Dependent Variable Mean } & 0.362 & 0.388 & 0.425 & 0.751 & 0.359 & 0.262 & 0.102 \\
\hline & \multicolumn{7}{|c|}{ Panel C: PKH Experiment — Formal Elites } \\
\hline & \multicolumn{3}{|c|}{ Receives PKH } & & \multicolumn{3}{|c|}{ Targeting List $\mathrm{PKH}$} \\
\hline & PMT & Community & Community & & PMT & Community & Community \\
\hline \multirow[t]{2}{*}{ Elite } & -0.008 & $-0.033 *$ & -0.017 & & -0.006 & -0.006 & -0.006 \\
\hline & $(0.015)$ & $(0.017)$ & $(0.023)$ & & $(0.009)$ & $(0.014)$ & $(0.019)$ \\
\hline \multirow[t]{2}{*}{ Elite x Elite Subtreatment } & & & -0.034 & & & & -0.001 \\
\hline & & & $(0.030)$ & & & & $(0.024)$ \\
\hline Observations & 1,860 & 1,935 & 1,935 & & 1,993 & 1,999 & 1,999 \\
\hline \multirow[t]{4}{*}{ Dependent Variable Mean } & 0.110 & 0.142 & 0.142 & & 0.0432 & 0.0770 & 0.0770 \\
\hline & \multicolumn{7}{|c|}{ Panel D: PKH Experiment — Informal Elites } \\
\hline & \multicolumn{3}{|c|}{ Receives PKH } & & \multicolumn{3}{|c|}{ Targeting List PKH } \\
\hline & PMT & Community & Community & & PMT & Community & Community \\
\hline Elite & -0.007 & -0.015 & -0.016 & & 0.005 & $-0.032 * *$ & $-0.044 * *$ \\
\hline & $(0.018)$ & $(0.018)$ & $(0.026)$ & & $(0.011)$ & $(0.015)$ & $(0.022)$ \\
\hline Elite x Elite Subtreatment & & & 0.001 & & & & 0.024 \\
\hline & & & $(0.037)$ & & & & $(0.030)$ \\
\hline Observations & 1,860 & 1,935 & 1,935 & & 1,993 & 1,999 & 1,999 \\
\hline Dependent Variable Mean & 0.110 & 0.142 & 0.142 & & 0.0432 & 0.0770 & 0.0770 \\
\hline
\end{tabular}

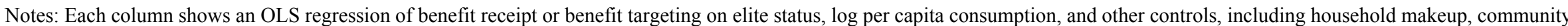

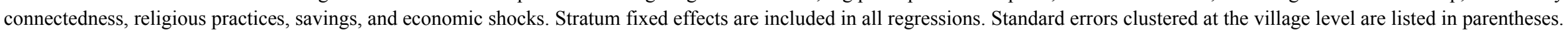
$* * * \mathrm{p}<0.01, * * \mathrm{p}<0.05, * \mathrm{p}<0.1$ 
Appendix Table 8: Formal Versus Informal Elites in Low-stakes experiment

\begin{tabular}{|c|c|c|c|c|c|c|}
\hline & \multicolumn{3}{|c|}{ Formal Elites } & \multicolumn{3}{|c|}{ Informal Elites } \\
\hline & $\begin{array}{l}\text { PMT } \\
\text { (1) }\end{array}$ & $\begin{array}{c}\text { Community } \\
\text { (2) }\end{array}$ & $\begin{array}{c}\text { Community } \\
\text { (3) }\end{array}$ & $\begin{array}{l}\text { PMT } \\
\text { (4) }\end{array}$ & $\begin{array}{c}\text { Community } \\
\text { (5) }\end{array}$ & $\begin{array}{c}\text { Community } \\
\text { (6) }\end{array}$ \\
\hline Elite & $\begin{array}{c}-0.054 * * \\
(0.022)\end{array}$ & $\begin{array}{c}-0.075 * * * \\
(0.026)\end{array}$ & $\begin{array}{c}-0.105 * * * \\
(0.037)\end{array}$ & $\begin{array}{l}-0.021 \\
(0.028)\end{array}$ & $\begin{array}{c}-0.103 * * * \\
(0.026)\end{array}$ & $\begin{array}{c}-0.100 * * * \\
(0.026)\end{array}$ \\
\hline Log Consumption & $\begin{array}{c}-0.194 * * * \\
(0.016)\end{array}$ & $\begin{array}{c}-0.207 * * * \\
(0.016)\end{array}$ & $\begin{array}{c}-0.207 * * * \\
(0.016)\end{array}$ & $\begin{array}{c}-0.196 * * * \\
(0.016)\end{array}$ & $\begin{array}{c}-0.205 * * * \\
(0.016)\end{array}$ & $\begin{array}{c}-0.204 * * * \\
(0.016)\end{array}$ \\
\hline Elite Subtreatment & & & $\begin{array}{l}-0.011 \\
(0.026)\end{array}$ & & & $\begin{array}{c}0.008 \\
(0.024)\end{array}$ \\
\hline Elite $\mathrm{x}$ Elite Subtreatment & & & $\begin{array}{c}0.059 \\
(0.050)\end{array}$ & & & $\begin{array}{l}-0.033 \\
(0.035)\end{array}$ \\
\hline Observations & 1,814 & 1,881 & 1,881 & 1,814 & 1,881 & 1,881 \\
\hline Dependent Variable Mean & 0.294 & 0.313 & 0.313 & 0.294 & 0.313 & 0.313 \\
\hline
\end{tabular}

Notes: Each column shows an OLS regression of benefit receipt or benefit targeting on elite status and log per capita consumption. Stratum fixed effects are included in all regressions. Standard errors clustered at the village level are listed in parentheses. $* * * \mathrm{p}<0.01,{ }^{* *} \mathrm{p}<0.05, * \mathrm{p}<0.1$ 
Appendix Table 9A: Do Formal Elites Capture Targeted Programs? Robustness to Village Restrictions

\begin{tabular}{|c|c|c|c|}
\hline & \multicolumn{3}{|c|}{ Receives PKH } \\
\hline & $\begin{array}{c}\text { PMT } \\
(1) \\
\end{array}$ & $\begin{array}{c}\text { Community } \\
\text { (2) }\end{array}$ & $\begin{array}{c}\text { Community } \\
\text { (3) }\end{array}$ \\
\hline \multicolumn{4}{|c|}{ Panel A: Drop all in kecamatans with $>=1$ village dropped } \\
\hline \multirow[t]{2}{*}{ Elite } & $-0.031 * *$ & $-0.045 * * *$ & -0.034 \\
\hline & $(0.015)$ & $(0.016)$ & $(0.024)$ \\
\hline \multirow[t]{2}{*}{ Log Consumption } & $-0.108 * * *$ & $-0.121 * * *$ & $-0.122 * * *$ \\
\hline & $(0.016)$ & $(0.015)$ & $(0.015)$ \\
\hline \multirow[t]{2}{*}{ Elite Subtreatment } & & & -0.015 \\
\hline & & & $(0.023)$ \\
\hline \multirow[t]{2}{*}{ Elite x Elite Subtreatment } & & & -0.023 \\
\hline & & & $(0.031)$ \\
\hline Observations & 1,714 & 1,752 & 1,752 \\
\hline Dependent Variable Mean & 0.113 & 0.142 & 0.142 \\
\hline \multicolumn{4}{|c|}{ Panel B: Drop all in kecamatans with $>=10 \%$ of villages dropped } \\
\hline \multirow[t]{2}{*}{ Elite } & $-0.031 * *$ & $-0.045 * * *$ & -0.028 \\
\hline & $(0.015)$ & $(0.016)$ & $(0.024)$ \\
\hline \multirow[t]{2}{*}{ Log Consumption } & $-0.108 * * *$ & $-0.121 * * *$ & $-0.122 * * *$ \\
\hline & $(0.016)$ & $(0.015)$ & $(0.015)$ \\
\hline \multirow[t]{2}{*}{ Elite Subtreatment } & & & -0.010 \\
\hline & & & $(0.024)$ \\
\hline \multirow[t]{2}{*}{ Elite $\mathrm{x}$ Elite Subtreatment } & & & -0.034 \\
\hline & & & $(0.032)$ \\
\hline Observations & 1,744 & 1,790 & 1,790 \\
\hline Dependent Variable Mean & 0.111 & 0.142 & 0.142 \\
\hline \multicolumn{4}{|c|}{ Panel C: Drop all villages dropped in new study } \\
\hline \multirow[t]{2}{*}{ Elite } & $-0.035 * *$ & $-0.043 * * *$ & -0.020 \\
\hline & $(0.015)$ & $(0.015)$ & $(0.023)$ \\
\hline \multirow[t]{2}{*}{ Log Consumption } & $-0.097 * * *$ & $-0.126 * * *$ & $-0.127 * * *$ \\
\hline & $(0.015)$ & $(0.015)$ & $(0.015)$ \\
\hline \multirow[t]{2}{*}{ Elite Subtreatment } & & & 0.001 \\
\hline & & & $(0.023)$ \\
\hline \multirow[t]{2}{*}{ Elite $\mathrm{x}$ Elite Subtreatment } & & & -0.046 \\
\hline & & & $(0.031)$ \\
\hline Observations & 1,834 & 1,869 & 1,869 \\
\hline Dependent Variable Mean & 0.111 & 0.141 & 0.141 \\
\hline \multicolumn{4}{|c|}{ Panel D: Drop all in kecamatans with $>=50 \%$ villages dropped, and those in new study } \\
\hline \multirow[t]{2}{*}{ Elite } & $-0.035 * *$ & $-0.043 * * *$ & -0.019 \\
\hline & $(0.015)$ & $(0.015)$ & $(0.023)$ \\
\hline \multirow[t]{2}{*}{ Log Consumption } & $-0.097 * * *$ & $-0.126 * * *$ & $-0.127 * * *$ \\
\hline & $(0.015)$ & $(0.015)$ & $(0.015)$ \\
\hline \multirow[t]{2}{*}{ Elite Subtreatment } & & & 0.003 \\
\hline & & & $(0.024)$ \\
\hline \multirow[t]{2}{*}{ Elite x Elite Subtreatment } & & & -0.049 \\
\hline & & & $(0.031)$ \\
\hline Observations & 1,834 & 1,849 & 1,849 \\
\hline Dependent Variable Mean & 0.111 & 0.142 & 0.142 \\
\hline
\end{tabular}


Appendix Table 9B: Do Informal Elites Capture Targeted Programs? Robustness to Village Restrictions

\begin{tabular}{|c|c|c|c|}
\hline & \multicolumn{3}{|c|}{ Receives PKH } \\
\hline & $\begin{array}{c}\text { PMT } \\
(1) \\
\end{array}$ & $\begin{array}{c}\text { Community } \\
\text { (2) }\end{array}$ & $\begin{array}{c}\text { Community } \\
\text { (3) }\end{array}$ \\
\hline \multicolumn{4}{|c|}{ Panel A: Drop all in kecamatans with $>=1$ village dropped } \\
\hline \multirow[t]{2}{*}{ Elite } & -0.026 & -0.013 & -0.014 \\
\hline & $(0.018)$ & $(0.020)$ & $(0.028)$ \\
\hline \multirow[t]{2}{*}{ Log Consumption } & $-0.109 * * *$ & $-0.125 * * *$ & $-0.125 * * *$ \\
\hline & $(0.016)$ & $(0.015)$ & $(0.015)$ \\
\hline \multirow[t]{2}{*}{ Elite Subtreatment } & & & -0.021 \\
\hline & & & $(0.025)$ \\
\hline \multirow[t]{2}{*}{ Elite x Elite Subtreatment } & & & 0.003 \\
\hline & & & $(0.040)$ \\
\hline Observations & 1,714 & 1,752 & 1,752 \\
\hline Dependent Variable Mean & 0.113 & 0.142 & 0.142 \\
\hline \multicolumn{4}{|c|}{ Panel B: Drop all in kecamatans with $>=10 \%$ of villages dropped } \\
\hline \multirow[t]{2}{*}{ Elite } & -0.026 & -0.017 & -0.016 \\
\hline & $(0.018)$ & $(0.019)$ & $(0.027)$ \\
\hline \multirow[t]{2}{*}{ Log Consumption } & $-0.108 * * *$ & $-0.124 * * *$ & $-0.124 * * *$ \\
\hline & $(0.016)$ & $(0.015)$ & $(0.015)$ \\
\hline \multirow[t]{2}{*}{ Elite Subtreatment } & & & -0.018 \\
\hline & & & $(0.025)$ \\
\hline \multirow[t]{2}{*}{ Elite $x$ Elite Subtreatment } & & & -0.002 \\
\hline & & & $(0.040)$ \\
\hline Observations & 1,744 & 1,790 & 1,790 \\
\hline Dependent Variable Mean & 0.111 & 0.142 & 0.142 \\
\hline \multicolumn{4}{|c|}{ Panel C: Drop all villages dropped in new study } \\
\hline \multirow[t]{2}{*}{ Elite } & $-0.033 *$ & -0.016 & -0.013 \\
\hline & $(0.018)$ & $(0.019)$ & $(0.027)$ \\
\hline \multirow[t]{2}{*}{ Log Consumption } & $-0.098 * * *$ & $-0.129 * * *$ & $-0.129 * * *$ \\
\hline & $(0.015)$ & $(0.015)$ & $(0.015)$ \\
\hline \multirow[t]{2}{*}{ Elite Subtreatment } & & & -0.010 \\
\hline & & & $(0.025)$ \\
\hline \multirow[t]{2}{*}{ Elite $x$ Elite Subtreatment } & & & -0.007 \\
\hline & & & $(0.039)$ \\
\hline Observations & 1,834 & 1,869 & 1,869 \\
\hline Dependent Variable Mean & 0.111 & 0.141 & 0.141 \\
\hline \multicolumn{4}{|c|}{ Panel D: Drop all in kecamatans with $>=50 \%$ villages dropped, and those in new study } \\
\hline \multirow[t]{2}{*}{ Elite } & $-0.033 *$ & -0.015 & -0.012 \\
\hline & $(0.018)$ & $(0.019)$ & $(0.027)$ \\
\hline \multirow[t]{2}{*}{ Log Consumption } & $-0.098 * * *$ & $-0.129 * * *$ & $-0.129 * * *$ \\
\hline & $(0.015)$ & $(0.015)$ & $(0.015)$ \\
\hline \multirow[t]{2}{*}{ Elite Subtreatment } & & & -0.008 \\
\hline & & & $(0.025)$ \\
\hline \multirow[t]{2}{*}{ Elite x Elite Subtreatment } & & & -0.008 \\
\hline & & & $(0.040)$ \\
\hline Observations & 1,834 & 1,849 & 1,849 \\
\hline Dependent Variable Mean & 0.111 & 0.142 & 0.142 \\
\hline
\end{tabular}




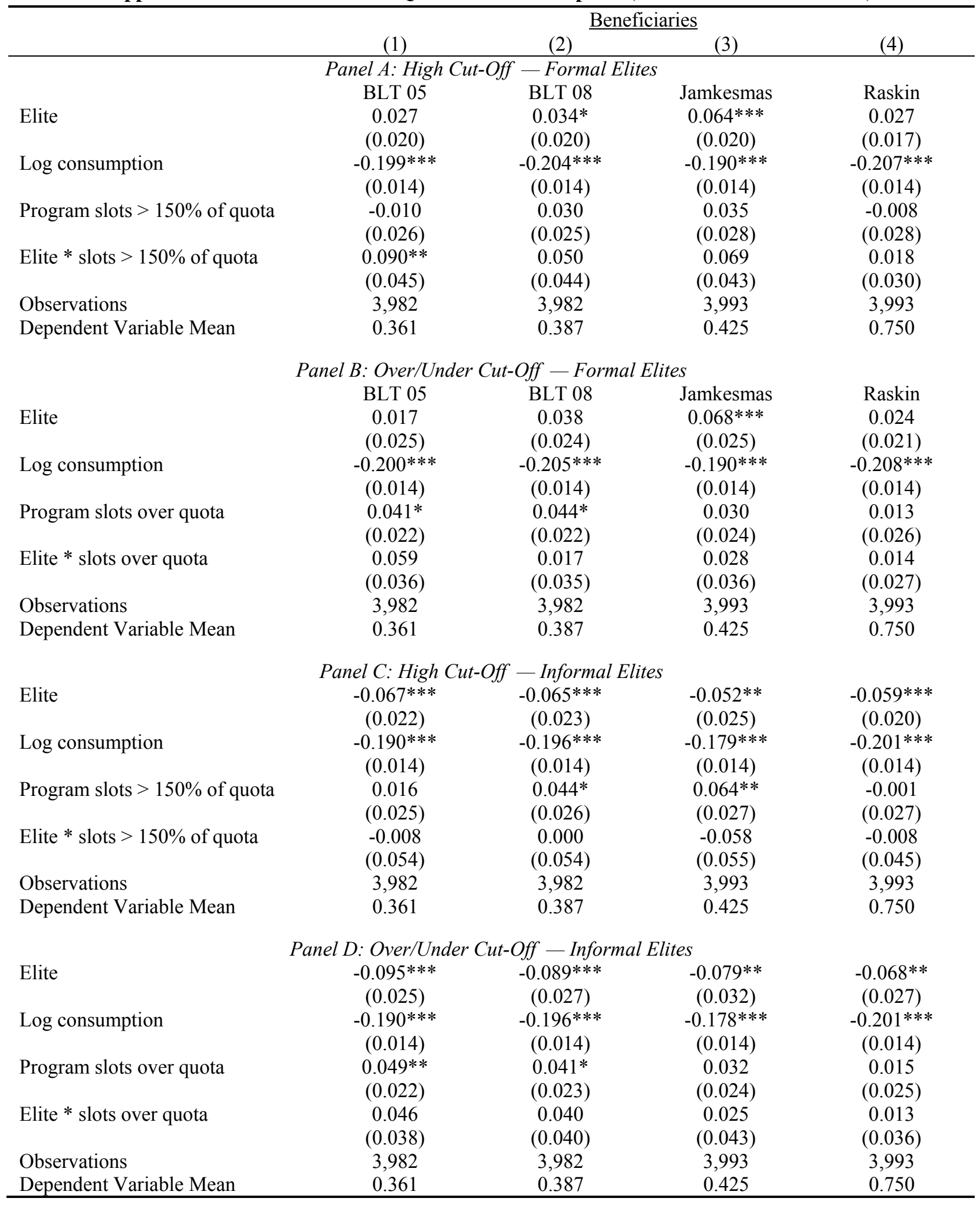

Notes: Each column shows an OLS regression of benefit receipt on elite status, log per capita consumption, a dummy for the level of program slots in the village relative to quota, and an interaction term. We compute the over-quota variable by comparing BLT 08 village allocation quota with the actual quota that should be given in that village. The allocation quota data for each village comes from PPLS 08 data which give us about 30 percent of household population or 18.5 million households. To generate the actual quota for each village, we first calculate the share of village quota to total district quota from poverty maps exercise using census 2010 data, and then scale that with the district quota predicted by SUSENAS to have equivalent poverty lines. Those who have more slots relative to actual poverty line are considered over-quota. In Panels A and C, the cut-off is set at 150\%; in Panels B and D, at 100\%. Stratum fixed effects are included in all regressions. Standard errors clustered at the village level are listed in parentheses. ${ }^{* * *} \mathrm{p}<0.01,{ }^{* *} \mathrm{p}<0.05,{ }^{*} \mathrm{p}<0$. 
Appendix Table 11: Do Elections Constrain Elites? (Formal Elites; Dropping RT Heads)

\begin{tabular}{|c|c|c|c|c|c|c|c|}
\hline & $(1)$ & $(2)$ & $(3)$ & (4) & $(5)$ & $(6)$ & $(7)$ \\
\hline & \multicolumn{7}{|c|}{ Panel A: Government Transfer Programs } \\
\hline & & Receiv & enefits & & & Targeting Lis & \\
\hline & BLT 05 & BLT 08 & Jamkesmas & Raskin & PPLS 1 & PPLS 2 & PPLS 3 \\
\hline \multirow[t]{2}{*}{ Elite $\mathrm{x}$ Elected } & -0.019 & -0.050 & $0.148^{* *}$ & 0.068 & 0.048 & 0.043 & 0.039 \\
\hline & $(0.066)$ & $(0.064)$ & $(0.062)$ & $(0.055)$ & $(0.057)$ & $(0.050)$ & $(0.036)$ \\
\hline Observations & 3,552 & 3,552 & 3,560 & 3,560 & 3,560 & 3,560 & 3,560 \\
\hline \multirow[t]{4}{*}{ Dependent Variable Mean } & 0.356 & 0.385 & 0.417 & 0.751 & 0.359 & 0.266 & 0.104 \\
\hline & \multicolumn{7}{|c|}{ Panel B: PKH Experiment } \\
\hline & & Receives PKH & & & & rgeting List $\mathrm{P}$ & \\
\hline & PMT & Community & Community & & PMT & Community & Community \\
\hline \multirow[t]{2}{*}{ Elite $\mathrm{x}$ Elected } & 0.011 & 0.050 & -0.050 & & $0.082 *$ & 0.003 & -0.031 \\
\hline & $(0.055)$ & $(0.072)$ & $(0.095)$ & & $(0.044)$ & $(0.064)$ & $(0.054)$ \\
\hline Elite $\mathrm{x}$ Elite Subtreatment $\mathrm{x}$ & & & 0.182 & & & & 0.074 \\
\hline Elected & & & $(0.115)$ & & & & $(0.101)$ \\
\hline Observations & 1,661 & 1,713 & 1,713 & & 1,787 & 1,773 & 1,773 \\
\hline Dependent Variable Mean & 0.115 & 0.148 & 0.148 & & 0.0453 & 0.0812 & 0.0812 \\
\hline
\end{tabular}

Notes: Each column shows an OLS regression of benefit receipt or benefit targeting on elite status, elected status, log per capita consumption, urban status, and interaction terms. Stratum fixed effects are included in all regressions. Standard errors clustered at the village level are listed in parentheses. $* * * p<0.01, * * \mathrm{p}<0.05, * \mathrm{p}<0.1$ 
Appendix Table 12A: Probit Model of Benefit Receipt (All Elites)

\begin{tabular}{|c|c|c|c|c|c|}
\hline VARIABLES & $\begin{array}{c}1) \\
\text { PKH }\end{array}$ & $\begin{array}{c}(2) \\
\text { BLT 05 }\end{array}$ & $\begin{array}{c}3) \\
\text { BLT 08 }\end{array}$ & $\begin{array}{c}\text { (4) } \\
\text { Jamkesmas }\end{array}$ & $\begin{array}{c}\text { (5) } \\
\text { Raskin }\end{array}$ \\
\hline Elite & $\begin{array}{l}-0.128 \\
(0.088)\end{array}$ & $\begin{array}{l}-0.003 \\
(0.050)\end{array}$ & $\begin{array}{c}0.050 \\
(0.050)\end{array}$ & $\begin{array}{c}0.045 \\
(0.049)\end{array}$ & $\begin{array}{c}0.038 \\
(0.055)\end{array}$ \\
\hline Log per capita consumption & $\begin{array}{l}-0.071 \\
(0.093)\end{array}$ & $\begin{array}{c}-0.228 * * * \\
(0.055)\end{array}$ & $\begin{array}{c}-0.238 * * * \\
(0.054)\end{array}$ & $\begin{array}{c}-0.346 * * * \\
(0.053)\end{array}$ & $\begin{array}{c}-0.391 * * * \\
(0.058)\end{array}$ \\
\hline PMT score & $\begin{array}{c}-1.295^{* * *} \\
(0.146)\end{array}$ & $\begin{array}{c}-0.560 * * * \\
(0.082)\end{array}$ & $\begin{array}{c}-0.608 * * * \\
(0.081)\end{array}$ & $\begin{array}{c}-0.304 * * * \\
(0.077)\end{array}$ & $\begin{array}{c}-0.701 * * * \\
(0.087)\end{array}$ \\
\hline Log household size & $\begin{array}{c}0.071 \\
(0.132)\end{array}$ & $\begin{array}{l}-0.010 \\
(0.077)\end{array}$ & $\begin{array}{c}-0.005 \\
(0.076)\end{array}$ & $\begin{array}{c}0.059 \\
(0.074)\end{array}$ & $\begin{array}{c}-0.395 * * * \\
(0.084)\end{array}$ \\
\hline Share of children in household & $\begin{array}{c}0.793 * * * \\
(0.234)\end{array}$ & $\begin{array}{c}0.612 * * * \\
(0.138)\end{array}$ & $\begin{array}{c}0.390 * * * \\
(0.136)\end{array}$ & $\begin{array}{c}0.208 \\
(0.132)\end{array}$ & $\begin{array}{l}0.250^{*} \\
(0.150)\end{array}$ \\
\hline Connected with other households & $\begin{array}{l}-0.018 \\
(0.019)\end{array}$ & $\begin{array}{c}0.010 \\
(0.010)\end{array}$ & $\begin{array}{c}0.008 \\
(0.010)\end{array}$ & $\begin{array}{c}0.033 * * * \\
(0.010)\end{array}$ & $\begin{array}{c}0.035 * * * \\
(0.011)\end{array}$ \\
\hline Having family members outside the village & $\begin{array}{c}0.013 \\
(0.028)\end{array}$ & $\begin{array}{c}0.012 \\
(0.018)\end{array}$ & $\begin{array}{c}0.013 \\
(0.018)\end{array}$ & $\begin{array}{l}-0.032^{*} \\
(0.018)\end{array}$ & $\begin{array}{l}-0.013 \\
(0.020)\end{array}$ \\
\hline Participating in religious groups & $\begin{array}{c}-0.249 * * * \\
(0.073)\end{array}$ & $\begin{array}{c}0.119 * * * \\
(0.045)\end{array}$ & $\begin{array}{c}0.099 * * \\
(0.045)\end{array}$ & $\begin{array}{l}-0.058 \\
(0.043)\end{array}$ & $\begin{array}{c}0.125^{* *} \\
(0.049)\end{array}$ \\
\hline Participating in community projects & $\begin{array}{c}0.068 \\
(0.084)\end{array}$ & $\begin{array}{l}-0.013 \\
(0.052)\end{array}$ & $\begin{array}{l}-0.073 \\
(0.051)\end{array}$ & $\begin{array}{l}-0.051 \\
(0.050)\end{array}$ & $\begin{array}{c}-0.109 * \\
(0.058)\end{array}$ \\
\hline Contributing money to village projects & $\begin{array}{l}-0.131 \\
(0.086)\end{array}$ & $\begin{array}{l}-0.027 \\
(0.049)\end{array}$ & $\begin{array}{l}-0.011 \\
(0.049)\end{array}$ & $\begin{array}{l}-0.020 \\
(0.047)\end{array}$ & $\begin{array}{c}-0.149 * * * \\
(0.052)\end{array}$ \\
\hline Working hard & $\begin{array}{c}-0.072 * * * \\
(0.024)\end{array}$ & $\begin{array}{c}-0.074 * * * \\
(0.014)\end{array}$ & $\begin{array}{c}-0.059 * * * \\
(0.014)\end{array}$ & $\begin{array}{c}-0.061 * * * \\
(0.014)\end{array}$ & $\begin{array}{c}-0.009 \\
(0.015)\end{array}$ \\
\hline Friendliness & $\begin{array}{c}0.011 \\
(0.027)\end{array}$ & $\begin{array}{c}0.070 * * * \\
(0.015)\end{array}$ & $\begin{array}{c}0.040 * * * \\
(0.015)\end{array}$ & $\begin{array}{c}0.062 * * * \\
(0.015)\end{array}$ & $\begin{array}{c}0.042^{* *} \\
(0.017)\end{array}$ \\
\hline Total savings amount & $\begin{array}{l}-0.000 \\
(0.000)\end{array}$ & $\begin{array}{l}-0.000 \\
(0.000)\end{array}$ & $\begin{array}{l}-0.000 \\
(0.000)\end{array}$ & $\begin{array}{l}-0.000 \\
(0.000)\end{array}$ & $\begin{array}{l}-0.000 \\
(0.000)\end{array}$ \\
\hline Share of savings in bank & $\begin{array}{l}-0.091 \\
(0.166)\end{array}$ & $\begin{array}{c}-0.533 * * * \\
(0.086)\end{array}$ & $\begin{array}{c}-0.523 * * * \\
(0.084)\end{array}$ & $\begin{array}{c}-0.231 * * * \\
(0.075)\end{array}$ & $\begin{array}{c}-0.448 * * * \\
(0.074)\end{array}$ \\
\hline Share of debt & $\begin{array}{c}-0.043 * * \\
(0.019)\end{array}$ & $\begin{array}{c}-0.020 * * * \\
(0.007)\end{array}$ & $\begin{array}{c}-0.014 * * \\
(0.006)\end{array}$ & $\begin{array}{c}-0.015^{* *} \\
(0.006)\end{array}$ & $\begin{array}{c}-0.021 * * * \\
(0.006)\end{array}$ \\
\hline Being ethnic minority & $\begin{array}{c}0.091 \\
(0.085)\end{array}$ & $\begin{array}{c}0.170 * * * \\
(0.052)\end{array}$ & $\begin{array}{l}0.096^{*} \\
(0.051)\end{array}$ & $\begin{array}{c}0.263 * * * \\
(0.050)\end{array}$ & $\begin{array}{c}0.175^{* * *} \\
(0.057)\end{array}$ \\
\hline Being religious minority & $\begin{array}{c}0.276 \\
(0.244)\end{array}$ & $\begin{array}{l}-0.200 \\
(0.166)\end{array}$ & $\begin{array}{c}-0.405 * * \\
(0.172)\end{array}$ & $\begin{array}{c}-0.364 * * \\
(0.159)\end{array}$ & $\begin{array}{c}-0.454 * * * \\
(0.154)\end{array}$ \\
\hline Household head has elementary education or less & $\begin{array}{c}0.138 \\
(0.092)\end{array}$ & $\begin{array}{c}0.238 * * * \\
(0.051)\end{array}$ & $\begin{array}{c}0.248 * * * \\
(0.050)\end{array}$ & $\begin{array}{c}0.169 * * * \\
(0.049)\end{array}$ & $\begin{array}{c}0.262 * * * \\
(0.055)\end{array}$ \\
\hline Household head is widow & $\begin{array}{c}0.351^{* *} \\
(0.146)\end{array}$ & $\begin{array}{l}-0.102 \\
(0.106)\end{array}$ & $\begin{array}{l}-0.013 \\
(0.105)\end{array}$ & $\begin{array}{l}-0.062 \\
(0.104)\end{array}$ & $\begin{array}{c}0.062 \\
(0.120)\end{array}$ \\
\hline Household head is disabled & $\begin{array}{l}0.241^{*} \\
(0.123)\end{array}$ & $\begin{array}{c}0.209^{* *} \\
(0.089)\end{array}$ & $\begin{array}{c}0.091 \\
(0.089)\end{array}$ & $\begin{array}{c}0.085 \\
(0.087)\end{array}$ & $\begin{array}{c}0.104 \\
(0.104)\end{array}$ \\
\hline Household experienced death of family member & $\begin{array}{c}0.103 \\
(0.227)\end{array}$ & $\begin{array}{l}-0.012 \\
(0.151)\end{array}$ & $\begin{array}{c}0.091 \\
(0.149)\end{array}$ & $\begin{array}{c}0.212 \\
(0.150)\end{array}$ & $\begin{array}{l}0.323^{*} \\
(0.193)\end{array}$ \\
\hline Household has sick family member & $\begin{array}{c}0.042 \\
(0.097)\end{array}$ & $\begin{array}{l}0.127^{* *} \\
(0.060)\end{array}$ & $\begin{array}{l}0.104^{*} \\
(0.060)\end{array}$ & $\begin{array}{c}0.016 \\
(0.059)\end{array}$ & $\begin{array}{l}-0.042 \\
(0.067)\end{array}$ \\
\hline Household experienced income shock & $\begin{array}{l}-0.085 \\
(0.074)\end{array}$ & $\begin{array}{c}0.019 \\
(0.045)\end{array}$ & $\begin{array}{l}-0.045 \\
(0.044)\end{array}$ & $\begin{array}{l}-0.072^{*} \\
(0.043)\end{array}$ & $\begin{array}{l}-0.019 \\
(0.050)\end{array}$ \\
\hline Tobacco and/or alcohol consumption & $\begin{array}{c}0.502 * * * \\
(0.155)\end{array}$ & $\begin{array}{l}0.191^{*} \\
(0.106)\end{array}$ & $\begin{array}{l}0.165 \\
(0.105)\end{array}$ & $\begin{array}{c}0.304 * * * \\
(0.100)\end{array}$ & $\begin{array}{c}0.484 * * * \\
(0.129)\end{array}$ \\
\hline Constant & $\begin{array}{l}15.664 * * * \\
(1.996)\end{array}$ & $\begin{array}{l}9.351 * * * \\
(1.093)\end{array}$ & $\begin{array}{l}10.386^{* * *} \\
(1.080)\end{array}$ & $\begin{array}{c}7.935 * * * \\
(1.026)\end{array}$ & $\begin{array}{l}14.992 * * * \\
(1.139)\end{array}$ \\
\hline $\begin{array}{l}\text { Observations } \\
\text { Dependent Variable Mean }\end{array}$ & $\begin{array}{c}3,992 \\
0.0601\end{array}$ & $\begin{array}{l}3,981 \\
0.362\end{array}$ & $\begin{array}{l}3,981 \\
0.388\end{array}$ & $\begin{array}{l}3,992 \\
0.425\end{array}$ & $\begin{array}{l}3,992 \\
0.751\end{array}$ \\
\hline
\end{tabular}

Notes: Probit model from social welfare calculation. Each column shows a probit regression of benefit receipt on elite status, $\log$ per capita consumption, and other controls. Standard errors clustered at the village level are listed in parentheses. $\quad * * * \mathrm{p}<0.01,{ }^{* *} \mathrm{p}<0.05,{ }^{*} \mathrm{p}<0.1$ 
Appendix Table 12B: Probit Model of Benefit Receipt (Formal Elites)

\begin{tabular}{|c|c|c|c|c|c|}
\hline VARIABLES & $\begin{array}{c}(1) \\
\text { PKH } \\
\end{array}$ & $\begin{array}{c}(2) \\
\text { BLT 05 } \\
\end{array}$ & $\begin{array}{c}(3) \\
\text { BLT } 08 \\
\end{array}$ & $\begin{array}{c}(4) \\
\text { Jamkesmas } \\
\end{array}$ & $\begin{array}{c}(5) \\
\text { Raskin } \\
\end{array}$ \\
\hline Elite & $\begin{array}{l}-0.113 \\
(0.097)\end{array}$ & $\begin{array}{c}0.133 * * \\
(0.054)\end{array}$ & $\begin{array}{c}0.165^{* * *} * \\
(0.054)\end{array}$ & $\begin{array}{c}0.227 * * * \\
(0.052)\end{array}$ & $\begin{array}{l}0.119 * * \\
(0.060)\end{array}$ \\
\hline Log per capita consumption & $\begin{array}{l}-0.073 \\
(0.093)\end{array}$ & $\begin{array}{c}-0.232 * * * \\
(0.055)\end{array}$ & $\begin{array}{c}-0.241 * * * \\
(0.054)\end{array}$ & $\begin{array}{c}-0.353 * * * \\
(0.053)\end{array}$ & $\begin{array}{c}-0.392 * * * \\
(0.058)\end{array}$ \\
\hline PMT score & $\begin{array}{c}-1.296 * * * \\
(0.146)\end{array}$ & $\begin{array}{c}-0.560 * * * \\
(0.082)\end{array}$ & $\begin{array}{c}-0.608 * * * \\
(0.081)\end{array}$ & $\begin{array}{c}-0.303 * * * \\
(0.078)\end{array}$ & $\begin{array}{c}-0.700 * * * \\
(0.087)\end{array}$ \\
\hline Log household size & $\begin{array}{c}0.066 \\
(0.132)\end{array}$ & $\begin{array}{l}-0.010 \\
(0.077)\end{array}$ & $\begin{array}{l}-0.002 \\
(0.076)\end{array}$ & $\begin{array}{c}0.062 \\
(0.074)\end{array}$ & $\begin{array}{c}-0.392 * * * \\
(0.084)\end{array}$ \\
\hline Share of children in household & $\begin{array}{c}0.795 * * * \\
(0.234)\end{array}$ & $\begin{array}{c}0.633^{* * *} \\
(0.139)\end{array}$ & $\begin{array}{c}0.409 * * * \\
(0.137)\end{array}$ & $\begin{array}{l}0.233 * \\
(0.133)\end{array}$ & $\begin{array}{l}0.264 * \\
(0.150)\end{array}$ \\
\hline Connected with other households & $\begin{array}{l}-0.020 \\
(0.019)\end{array}$ & $\begin{array}{c}0.004 \\
(0.010)\end{array}$ & $\begin{array}{c}0.003 \\
(0.010)\end{array}$ & $\begin{array}{l}0.025 * * \\
(0.010)\end{array}$ & $\begin{array}{c}0.032 * * * \\
(0.011)\end{array}$ \\
\hline Having family members outside the village & $\begin{array}{c}0.012 \\
(0.028)\end{array}$ & $\begin{array}{c}0.010 \\
(0.018)\end{array}$ & $\begin{array}{c}0.011 \\
(0.018)\end{array}$ & $\begin{array}{c}-0.035 * * \\
(0.018)\end{array}$ & $\begin{array}{l}-0.015 \\
(0.020)\end{array}$ \\
\hline Participating in religious groups & $\begin{array}{c}-0.254 * * * \\
(0.073)\end{array}$ & $\begin{array}{c}0.112 * * \\
(0.045)\end{array}$ & $\begin{array}{c}0.095 * * \\
(0.045)\end{array}$ & $\begin{array}{l}-0.066 \\
(0.043)\end{array}$ & $\begin{array}{l}0.122 * * \\
(0.049)\end{array}$ \\
\hline Participating in community projects & $\begin{array}{c}0.064 \\
(0.084)\end{array}$ & $\begin{array}{l}-0.015 \\
(0.052)\end{array}$ & $\begin{array}{l}-0.074 \\
(0.051)\end{array}$ & $\begin{array}{l}-0.055 \\
(0.050)\end{array}$ & $\begin{array}{l}-0.112 * \\
(0.058)\end{array}$ \\
\hline Contributing money to village projects & $\begin{array}{l}-0.133 \\
(0.086)\end{array}$ & $\begin{array}{l}-0.033 \\
(0.049)\end{array}$ & $\begin{array}{l}-0.016 \\
(0.049)\end{array}$ & $\begin{array}{l}-0.028 \\
(0.047)\end{array}$ & $\begin{array}{c}-0.154 * * * \\
(0.052)\end{array}$ \\
\hline Working hard & $\begin{array}{c}-0.072 * * * \\
(0.024)\end{array}$ & $\begin{array}{c}-0.073 * * * \\
(0.014)\end{array}$ & $\begin{array}{c}-0.058 * * * \\
(0.014)\end{array}$ & $\begin{array}{c}-0.059 * * * \\
(0.014)\end{array}$ & $\begin{array}{l}-0.008 \\
(0.015)\end{array}$ \\
\hline Friendliness & $\begin{array}{c}0.009 \\
(0.027)\end{array}$ & $\begin{array}{c}0.060 * * * \\
(0.015)\end{array}$ & $\begin{array}{c}0.031 * * \\
(0.015)\end{array}$ & $\begin{array}{c}0.048 * * * \\
(0.015)\end{array}$ & $\begin{array}{c}0.036 * * \\
(0.017)\end{array}$ \\
\hline Total savings amount & $\begin{array}{l}-0.000 \\
(0.000)\end{array}$ & $\begin{array}{c}-0.000 \\
(0.000)\end{array}$ & $\begin{array}{l}-0.000 \\
(0.000)\end{array}$ & $\begin{array}{c}0.000 \\
(0.000)\end{array}$ & $\begin{array}{l}-0.000 \\
(0.000)\end{array}$ \\
\hline Share of savings in bank & $\begin{array}{l}-0.096 \\
(0.165)\end{array}$ & $\begin{array}{c}-0.538 * * * \\
(0.086)\end{array}$ & $\begin{array}{c}-0.526 * * * \\
(0.084)\end{array}$ & $\begin{array}{c}-0.236 * * * \\
(0.075)\end{array}$ & $\begin{array}{c}-0.451 * * * \\
(0.074)\end{array}$ \\
\hline Share of debt & $\begin{array}{c}-0.044 * * \\
(0.019)\end{array}$ & $\begin{array}{c}-0.021 * * * \\
(0.007)\end{array}$ & $\begin{array}{c}-0.014 * * \\
(0.006)\end{array}$ & $\begin{array}{c}-0.015 * * * \\
(0.006)\end{array}$ & $\begin{array}{c}-0.021 * * * \\
(0.006)\end{array}$ \\
\hline Being ethnic minority & $\begin{array}{c}0.095 \\
(0.084)\end{array}$ & $\begin{array}{c}0.169^{* * *} \\
(0.052)\end{array}$ & $\begin{array}{l}0.093 * \\
(0.051)\end{array}$ & $\begin{array}{c}0.260 * * * \\
(0.050)\end{array}$ & $\begin{array}{c}0.172 * * * \\
(0.057)\end{array}$ \\
\hline Being religious minority & $\begin{array}{c}0.263 \\
(0.245)\end{array}$ & $\begin{array}{l}-0.195 \\
(0.166)\end{array}$ & $\begin{array}{c}-0.397 * * \\
(0.172)\end{array}$ & $\begin{array}{c}-0.358 * * \\
(0.159)\end{array}$ & $\begin{array}{c}-0.452 * * * \\
(0.153)\end{array}$ \\
\hline Household head has elementary education or less & $\begin{array}{c}0.140 \\
(0.092)\end{array}$ & $\begin{array}{c}0.245 * * * \\
(0.051)\end{array}$ & $\begin{array}{c}0.253 * * * \\
(0.050)\end{array}$ & $\begin{array}{c}0.178 * * * \\
(0.049)\end{array}$ & $\begin{array}{c}0.266 * * * \\
(0.055)\end{array}$ \\
\hline Household head is widow & $\begin{array}{c}0.351 * * \\
(0.147)\end{array}$ & $\begin{array}{c}-0.097 \\
(0.106)\end{array}$ & $\begin{array}{c}-0.009 \\
(0.105)\end{array}$ & $\begin{array}{c}-0.058 \\
(0.104)\end{array}$ & $\begin{array}{c}0.064 \\
(0.120)\end{array}$ \\
\hline Household head is disabled & $\begin{array}{c}0.246 * * \\
(0.123)\end{array}$ & $\begin{array}{c}0.209 * * \\
(0.089)\end{array}$ & $\begin{array}{c}0.089 \\
(0.089)\end{array}$ & $\begin{array}{c}0.083 \\
(0.087)\end{array}$ & $\begin{array}{c}0.102 \\
(0.104)\end{array}$ \\
\hline Household experienced death of family member & $\begin{array}{c}0.105 \\
(0.227)\end{array}$ & $\begin{array}{l}-0.025 \\
(0.151)\end{array}$ & $\begin{array}{c}0.080 \\
(0.150)\end{array}$ & $\begin{array}{c}0.200 \\
(0.151)\end{array}$ & $\begin{array}{c}0.315 \\
(0.193)\end{array}$ \\
\hline Household has sick family member & $\begin{array}{c}0.040 \\
(0.097)\end{array}$ & $\begin{array}{l}0.131 * * \\
(0.060)\end{array}$ & $\begin{array}{l}0.108 * \\
(0.060)\end{array}$ & $\begin{array}{c}0.023 \\
(0.059)\end{array}$ & $\begin{array}{l}-0.040 \\
(0.067)\end{array}$ \\
\hline Household experienced income shock & $\begin{array}{l}-0.086 \\
(0.074)\end{array}$ & $\begin{array}{c}0.017 \\
(0.045)\end{array}$ & $\begin{array}{l}-0.045 \\
(0.044)\end{array}$ & $\begin{array}{c}-0.074 * \\
(0.043)\end{array}$ & $\begin{array}{l}-0.019 \\
(0.050)\end{array}$ \\
\hline Tobacco and/or alcohol consumption & $\begin{array}{c}0.509 * * * \\
(0.155)\end{array}$ & $\begin{array}{l}0.180 * \\
(0.107)\end{array}$ & $\begin{array}{c}0.153 \\
(0.105)\end{array}$ & $\begin{array}{l}0.287 * * * \\
(0.101)\end{array}$ & $\begin{array}{l}0.476^{* * *} \\
(0.129)\end{array}$ \\
\hline Constant & $\begin{array}{c}15.699 * * * \\
(1.995)\end{array}$ & $\begin{array}{l}9.436^{* * *} \\
(1.093)\end{array}$ & $\begin{array}{c}10.446^{* * *} \\
(1.081)\end{array}$ & $\begin{array}{l}8.047 * * * \\
(1.028)\end{array}$ & $\begin{array}{l}15.006 * * * \\
(1.138)\end{array}$ \\
\hline $\begin{array}{l}\text { Observations } \\
\text { Dependent Variable Mean }\end{array}$ & $\begin{array}{c}3,992 \\
0.0601\end{array}$ & $\begin{array}{l}3,981 \\
0.362\end{array}$ & $\begin{array}{l}3,981 \\
0.388\end{array}$ & $\begin{array}{l}3,992 \\
0.425\end{array}$ & $\begin{array}{l}3,992 \\
0.751\end{array}$ \\
\hline
\end{tabular}

Notes: Probit model from social welfare calculation. Each column shows a probit regression of benefit receipt on elite status, log per capita consumption, and other controls. Standard errors clustered at the village level are listed in parentheses. $\quad * * * \mathrm{p}<0.01, * * \mathrm{p}<0.05, * \mathrm{p}<0.1$ 
Appendix Table 12C: Probit Model of Benefit Receipt (Informal Elites)

\begin{tabular}{|c|c|c|c|c|c|}
\hline VARIABLES & $\begin{array}{c}(1) \\
\text { PKH }\end{array}$ & $\begin{array}{c}(2) \\
\text { BLT 05 }\end{array}$ & $\begin{array}{c}\text { (3) } \\
\text { BLT 08 }\end{array}$ & $\begin{array}{c}\text { (4) } \\
\text { Jamkesmas }\end{array}$ & $\begin{array}{c}(5) \\
\text { Raskin }\end{array}$ \\
\hline Elite & $\begin{array}{l}-0.146 \\
(0.115)\end{array}$ & $\begin{array}{c}-0.192 * * * \\
(0.061)\end{array}$ & $\begin{array}{c}-0.136^{* *} \\
(0.060)\end{array}$ & $\begin{array}{c}-0.261 * * * \\
(0.058)\end{array}$ & $\begin{array}{l}-0.112^{*} \\
(0.063)\end{array}$ \\
\hline Log per capita consumption & $\begin{array}{l}-0.076 \\
(0.093)\end{array}$ & $\begin{array}{c}-0.222 * * * \\
(0.055)\end{array}$ & $\begin{array}{c}-0.231 * * * \\
(0.054)\end{array}$ & $\begin{array}{c}-0.335 * * * \\
(0.053)\end{array}$ & $\begin{array}{c}-0.383 * * * \\
(0.058)\end{array}$ \\
\hline PMT score & $\begin{array}{c}-1.292 * * * \\
(0.146)\end{array}$ & $\begin{array}{c}-0.559 * * * \\
(0.082)\end{array}$ & $\begin{array}{c}-0.608 * * * \\
(0.081)\end{array}$ & $\begin{array}{c}-0.304 * * * \\
(0.077)\end{array}$ & $\begin{array}{c}-0.702 * * * \\
(0.087)\end{array}$ \\
\hline Log household size & $\begin{array}{c}0.071 \\
(0.132)\end{array}$ & $\begin{array}{c}0.003 \\
(0.077)\end{array}$ & $\begin{array}{c}0.008 \\
(0.076)\end{array}$ & $\begin{array}{c}0.082 \\
(0.074)\end{array}$ & $\begin{array}{c}-0.383 * * * \\
(0.084)\end{array}$ \\
\hline Share of children in household & $\begin{array}{c}0.798 * * * \\
(0.234)\end{array}$ & $\begin{array}{c}0.602 * * * \\
(0.139)\end{array}$ & $\begin{array}{c}0.377 * * * \\
(0.136)\end{array}$ & $\begin{array}{c}0.186 \\
(0.133)\end{array}$ & $\begin{array}{c}0.237 \\
(0.150)\end{array}$ \\
\hline Connected with other households & $\begin{array}{l}-0.022 \\
(0.018)\end{array}$ & $\begin{array}{c}0.015 \\
(0.010)\end{array}$ & $\begin{array}{c}0.015 \\
(0.010)\end{array}$ & $\begin{array}{c}0.043^{* * *} \\
(0.010)\end{array}$ & $\begin{array}{c}0.041 * * * \\
(0.011)\end{array}$ \\
\hline Having family members outside the village & $\begin{array}{c}0.011 \\
(0.028)\end{array}$ & $\begin{array}{c}0.013 \\
(0.018)\end{array}$ & $\begin{array}{c}0.014 \\
(0.018)\end{array}$ & $\begin{array}{l}-0.031^{*} \\
(0.018)\end{array}$ & $\begin{array}{l}-0.012 \\
(0.020)\end{array}$ \\
\hline Participating in religious groups & $\begin{array}{c}-0.252 * * * \\
(0.073)\end{array}$ & $\begin{array}{c}0.125^{* * *} * \\
(0.045)\end{array}$ & $\begin{array}{c}0.107^{* *} \\
(0.045)\end{array}$ & $\begin{array}{l}-0.046 \\
(0.043)\end{array}$ & $\begin{array}{c}0.133 * * * \\
(0.049)\end{array}$ \\
\hline Participating in community projects & $\begin{array}{c}0.070 \\
(0.084)\end{array}$ & $\begin{array}{l}-0.007 \\
(0.052)\end{array}$ & $\begin{array}{l}-0.067 \\
(0.051)\end{array}$ & $\begin{array}{l}-0.042 \\
(0.050)\end{array}$ & $\begin{array}{c}-0.105^{*} \\
(0.058)\end{array}$ \\
\hline Contributing money to village projects & $\begin{array}{l}-0.130 \\
(0.086)\end{array}$ & $\begin{array}{l}-0.021 \\
(0.049)\end{array}$ & $\begin{array}{l}-0.004 \\
(0.049)\end{array}$ & $\begin{array}{l}-0.010 \\
(0.047)\end{array}$ & $\begin{array}{c}-0.144 * * * \\
(0.052)\end{array}$ \\
\hline Working hard & $\begin{array}{c}-0.071 * * * \\
(0.024)\end{array}$ & $\begin{array}{c}-0.075 * * * \\
(0.014)\end{array}$ & $\begin{array}{c}-0.060 * * * \\
(0.014)\end{array}$ & $\begin{array}{c}-0.063 * * * \\
(0.014)\end{array}$ & $\begin{array}{l}-0.010 \\
(0.015)\end{array}$ \\
\hline Friendliness & $\begin{array}{c}0.005 \\
(0.026)\end{array}$ & $\begin{array}{c}0.075^{* * *} * \\
(0.015)\end{array}$ & $\begin{array}{c}0.048 * * * \\
(0.015)\end{array}$ & $\begin{array}{c}0.074 * * * \\
(0.014)\end{array}$ & $\begin{array}{c}0.049 * * * \\
(0.016)\end{array}$ \\
\hline Total savings amount & $\begin{array}{c}0.000 \\
(0.000)\end{array}$ & $\begin{array}{l}-0.000 \\
(0.000)\end{array}$ & $\begin{array}{l}-0.000 \\
(0.000)\end{array}$ & $\begin{array}{c}0.000 \\
(0.000)\end{array}$ & $\begin{array}{l}-0.000 \\
(0.000)\end{array}$ \\
\hline Share of savings in bank & $\begin{array}{l}-0.094 \\
(0.165)\end{array}$ & $\begin{array}{c}-0.527 * * * \\
(0.086)\end{array}$ & $\begin{array}{c}-0.514 * * * \\
(0.084)\end{array}$ & $\begin{array}{c}-0.219 * * * \\
(0.075)\end{array}$ & $\begin{array}{c}-0.443 * * * \\
(0.074)\end{array}$ \\
\hline Share of debt & $\begin{array}{c}-0.044 * * \\
(0.019)\end{array}$ & $\begin{array}{c}-0.020 * * * \\
(0.007)\end{array}$ & $\begin{array}{c}-0.013 * * \\
(0.006)\end{array}$ & $\begin{array}{c}-0.014 * * \\
(0.006)\end{array}$ & $\begin{array}{c}-0.020 * * * \\
(0.006)\end{array}$ \\
\hline Being ethnic minority & $\begin{array}{c}0.089 \\
(0.085)\end{array}$ & $\begin{array}{c}0.160 * * * \\
(0.052)\end{array}$ & $\begin{array}{l}0.088^{*} \\
(0.051)\end{array}$ & $\begin{array}{c}0.248 * * * \\
(0.050)\end{array}$ & $\begin{array}{c}0.166^{* * *} \\
(0.058)\end{array}$ \\
\hline Being religious minority & $\begin{array}{c}0.279 \\
(0.244)\end{array}$ & $\begin{array}{l}-0.187 \\
(0.166)\end{array}$ & $\begin{array}{c}-0.398 * * \\
(0.172)\end{array}$ & $\begin{array}{c}-0.348^{* *} \\
(0.159)\end{array}$ & $\begin{array}{c}-0.446^{* * * *} \\
(0.154)\end{array}$ \\
\hline Household head has elementary education or less & $\begin{array}{c}0.138 \\
(0.092)\end{array}$ & $\begin{array}{c}0.228 * * * \\
(0.051)\end{array}$ & $\begin{array}{c}0.238 * * * \\
(0.050)\end{array}$ & $\begin{array}{c}0.150 * * * \\
(0.049)\end{array}$ & $\begin{array}{c}0.251 * * * \\
(0.055)\end{array}$ \\
\hline Household head is widow & $\begin{array}{c}0.357 * * \\
(0.146)\end{array}$ & $\begin{array}{l}-0.100 \\
(0.106)\end{array}$ & $\begin{array}{l}-0.013 \\
(0.105)\end{array}$ & $\begin{array}{l}-0.062 \\
(0.104)\end{array}$ & $\begin{array}{c}0.061 \\
(0.120)\end{array}$ \\
\hline Household head is disabled & $\begin{array}{l}0.241^{*} \\
(0.123)\end{array}$ & $\begin{array}{c}0.203^{* *} \\
(0.089)\end{array}$ & $\begin{array}{c}0.085 \\
(0.089)\end{array}$ & $\begin{array}{c}0.075 \\
(0.087)\end{array}$ & $\begin{array}{c}0.098 \\
(0.104)\end{array}$ \\
\hline Household experienced death of family member & $\begin{array}{c}0.099 \\
(0.227)\end{array}$ & $\begin{array}{l}-0.012 \\
(0.151)\end{array}$ & $\begin{array}{c}0.093 \\
(0.150)\end{array}$ & $\begin{array}{c}0.217 \\
(0.151)\end{array}$ & $\begin{array}{l}0.326^{*} \\
(0.193)\end{array}$ \\
\hline Household has sick family member & $\begin{array}{c}0.047 \\
(0.097)\end{array}$ & $\begin{array}{l}0.127^{* *} \\
(0.060)\end{array}$ & $\begin{array}{l}0.102^{*} \\
(0.060)\end{array}$ & $\begin{array}{c}0.013 \\
(0.059)\end{array}$ & $\begin{array}{l}-0.045 \\
(0.067)\end{array}$ \\
\hline Household experienced income shock & $\begin{array}{l}-0.088 \\
(0.074)\end{array}$ & $\begin{array}{c}0.024 \\
(0.045)\end{array}$ & $\begin{array}{l}-0.041 \\
(0.044)\end{array}$ & $\begin{array}{l}-0.065 \\
(0.043)\end{array}$ & $\begin{array}{l}-0.017 \\
(0.050)\end{array}$ \\
\hline Tobacco and/or alcohol consumption & $\begin{array}{c}0.489 * * * \\
(0.156)\end{array}$ & $\begin{array}{c}0.172 \\
(0.107)\end{array}$ & $\begin{array}{c}0.151 \\
(0.105)\end{array}$ & $\begin{array}{c}0.277 * * * \\
(0.101)\end{array}$ & $\begin{array}{c}0.473 * * * \\
(0.129)\end{array}$ \\
\hline Constant & $\begin{array}{l}15.688^{* * *} \\
(1.996)\end{array}$ & $\begin{array}{c}9.240 * * * \\
(1.093)\end{array}$ & $\begin{array}{c}10.257^{* * *} \\
(1.080)\end{array}$ & $\begin{array}{c}7.741 * * * \\
(1.027)\end{array}$ & $\begin{array}{l}14.888^{* * *} \\
(1.138)\end{array}$ \\
\hline $\begin{array}{l}\text { Observations } \\
\text { Dependent Variable Mean }\end{array}$ & $\begin{array}{c}3,992 \\
0.0601\end{array}$ & $\begin{array}{l}3,981 \\
0.362\end{array}$ & $\begin{array}{l}3,981 \\
0.388\end{array}$ & $\begin{array}{l}3,992 \\
0.425\end{array}$ & $\begin{array}{l}3,992 \\
0.751\end{array}$ \\
\hline
\end{tabular}

Notes: Probit model from social welfare calculation. Each column shows a probit regression of benefit receipt on elite status, $\log$ per capita consumption, and other controls. Standard errors clustered at the village level are listed in parentheses. $\quad * * * \mathrm{p}<0.01,{ }^{* *} \mathrm{p}<0.05,{ }^{*} \mathrm{p}<0.1$ 


\section{Appendix Table 13: Social Welfare Levels in PKH with Additional Counterfactual}

\begin{tabular}{|c|c|}
\hline & $\begin{array}{c}(1) \\
\text { PKH Experimen }\end{array}$ \\
\hline \multicolumn{2}{|c|}{ Panel A: Elites } \\
\hline \multicolumn{2}{|l|}{ Utility... } \\
\hline Without program & -6.689 \\
\hline With Elite on & -6.593 \\
\hline With Elite off & -6.594 \\
\hline Under perfect PMT-targeting & -6.540 \\
\hline Under perfect consumption targeting & -6.333 \\
\hline Taking PPLS, then perfect PMT & -6.557 \\
\hline \multicolumn{2}{|l|}{ Share of possible utility gain... } \\
\hline With Elite on & $26.82 \%$ \\
\hline With Elite off & $26.57 \%$ \\
\hline Under perfect PMT targeting & $41.71 \%$ \\
\hline Taking PPLS, then perfect PMT & $36.99 \%$ \\
\hline \multicolumn{2}{|c|}{ Panel B: Formal Elites } \\
\hline \multicolumn{2}{|l|}{ Utility... } \\
\hline Without program & -6.689 \\
\hline With Elite on & -6.593 \\
\hline With Elite off & -6.594 \\
\hline Under perfect PMT-targeting & -6.540 \\
\hline Under perfect consumption targeting & -6.333 \\
\hline Taking PPLS, then perfect PMT & -6.557 \\
\hline \multicolumn{2}{|l|}{ Share of possible utility gain... } \\
\hline With Elite on & $26.88 \%$ \\
\hline With Elite off & $26.63 \%$ \\
\hline Under perfect PMT targeting & $41.71 \%$ \\
\hline Taking PPLS, then perfect PMT & $36.99 \%$ \\
\hline \multicolumn{2}{|c|}{ Panel C: Informal Elites } \\
\hline \multicolumn{2}{|l|}{ Utility... } \\
\hline Without program & -6.689 \\
\hline With Elite on & -6.593 \\
\hline With Elite off & -6.593 \\
\hline Under perfect PMT-targeting & -6.540 \\
\hline Under perfect consumption targeting & -6.333 \\
\hline Taking PPLS, then perfect PMT & -6.557 \\
\hline \multicolumn{2}{|l|}{ Share of possible utility gain... } \\
\hline With Elite on & $26.86 \%$ \\
\hline With Elite off & $26.77 \%$ \\
\hline Under perfect PMT targeting & $41.71 \%$ \\
\hline Taking PPLS, then perfect PMT & $36.99 \%$ \\
\hline
\end{tabular}

Notes: Utility is calculated as a monotonically increasing function of $\log$ per capita consumption, $\mathrm{u}=-\left(\log (\mathrm{x})^{\wedge}-2\right) / 2$ (note that, under this formula, all utility is defined to be negative). Simulations are created with a probit model of benefit receipt, using our baseline calculations of consumption and PMT score, and a list of covariates. The probit model is shown in Appendix Table 12. 


\section{Appendix: Details on Experimental Design: NOT FOR PUBLICATION}

Treatment 1: PPLS (Status Quo)

In this treatment, targeting was accomplished through a combination of a proxy-means test (PMT) and input from local village leaders. First, for each experimental district, the government created a formula that mapped easily observable household characteristics into a single index using regression techniques (i.e. the PMT formula). ${ }^{28}$ Specifically, it created a list of 28 measures, encompassing the household's home attributes (wall type, roof type, etc.), assets (motorcycle, refrigerator, etc.), household composition, and household head's education and occupation. The measures also include location-based indicators, such as population density, distance to the district capital, existence of education and health facilities, and existence of semi-permanent marketplace. Using pre-existing surveys (SUSENAS (2010) and PODES (2008)), the government estimated the relationship between these variables and household per-capita consumption in order to create district-level formulas to predict consumption levels using these variables. ${ }^{29}$ Individuals with scores below each district's very poor line would then be considered financially eligible for the program.

Conducting a full census of households to collect the data that are needed to predict each household's consumption is prohibitively expensive. As such, the Indonesian government harnesses local information to determine which households should be interviewed. Specifically, for each village, the government enumerators were given a pre-printed list of households from the last targeting survey (PPLS 2008). When they arrived at a village, the enumerators showed the village leadership the list and then asked them to add additional households to the list. ${ }^{30}$ The enumerators also had flexibility to add more households to the potential list of interviewees based on their own subjective observation of households. Of the 6,406 households on the list, 16 percent were eliminated based on the initial screen, and 5,383

\footnotetext{
${ }^{28}$ The government designed the PMT questionnaire (this was used as a pilot of the questionnaire for the 2011 nation-wide targeting efforts.

${ }^{29}$ On average, these regressions had an $\mathrm{R}^{2}$ of 0.52 .

${ }^{30}$ For cost considerations, the new PMT was only conducted in the sub-village selected for our survey. In all remaining subvillages, the government determined eligibility in the same manner as in the non-experimental districts, i.e. they used the PPLS 2008 data to determine eligibility.
} 
households (or about 37.8 percent of the sub-villages) were given the full-PMT survey. ${ }^{31}$ After the data were collected and entered, each household was assigned a predicted consumption score based on the PMT formula. Those who were below the district's very poor line were considered as beneficiaries.

\section{Main Treatment 2: Community Input}

In the community-input treatment, the list of beneficiaries was determined through a poverty-ranking exercise that was conducted at a village meeting. First, the facilitator visited each sub-village in the village, informed the sub-village head about the program, and set a date for a community meeting. To vary the level of elite control in the meetings, we randomly varied who was invited to them: in half of the villages (randomly selected), we asked the local sub-village head to invite 5-8 local leaders, both formal and informal, to the meetings. In the other half, the full community was invited to the meetings so that the full community could potentially provide a check on the power of the elites to capture the targeting process. The facilitator and sub-village head heavily advertised the meeting to encourage full attendance. In many cases, the facilitators made door-to-door household visits in order to encourage attendance. On average, 15 percent of households in the village attended the meetings in the elite sub-treatment, while 59 percent did so in the community sub-treatment.

At the meeting, the facilitator first explained $\mathrm{PKH}$ and the purpose of the program. Having answered questions about the program itself, the facilitator would then display cards listing the poorest households in the sub-village according to the official poverty census (PPLS 08). The number of cards shown was roughly 75 percent of the sub-village's quota. Consulting the meeting attendants, the facilitator removed households with inaccurate information, i.e., households that a) no longer lived in the

\footnotetext{
${ }^{31}$ The pre-screening consists of 5 questions: is the household's average income per month in the past three months more than IDR 1,000,000 (USD 110); was the average transfer received per month in the past three months more than IDR 1,000,000 (USD 110); did they own a TV or refrigerator that cost more than IDR 1,000,000 (USD 110); was the value of their livestock productive building, and large agricultural tools owned more IDR 1,500,000 (USD 167); did they own a motor vehicle; and did they own jewelry worth more than IDR 1,000,000 (USD 100). Households that answered yes on either four or five of the questions were instantly disqualified and the survey ended.
} 
sub-village, or b) did not own at least one out of the three PKH criteria. The remaining households comprise the "poverty census" list.

To compile the next list (the "brainstorm" list), the facilitator first asked the meeting attendants to discuss characteristics they would associate with poverty in their sub-village. Next, the meeting attendants were asked to brainstorm for households they thought to be the most deserving of PKH in their subvillage, up to 100 percent of the sub-village's quota. After ensuring all the households listed own at least one of the three PKH criteria, the remaining households comprise the "brainstorm" list. At this point, the facilitator calculates the total number of households from both the poverty census and the brainstorm lists. In virtually all meetings, this number exceeds 100 percent of the sub-village's quota, so the facilitator leads the meeting attendants through a ranking exercise.

The ranking exercise that follows depended on which sub-treatment was used in the village. We randomly divided the villages into one of two sub-treatments: Add vs. Add and Replace. In the Add villages, attendants were asked to rank only the households in the brainstorm list, while the portion of the list that came from the last targeting survey remained unchanged. In the Add and Replace villages, attendants were asked to rank everyone in the combined list, allowing them to replace households from the last targeting survey.

The facilitator began the ranking exercise by shuffling the index cards with names of households to rank. They then presented the first two name cards from the stack to the attendants and asked, "Which of these two households is less well-off than the other?" Based on the attendants' response, the facilitator attached the cards to the wall in order. The facilitator then took another name from the stack and compared this name to the names on the wall. The process continued until all the index cards made up a sequential list, with one end labeled as "most well-off" (paling mampu) and the other side labeled as "poorest" (paling miskin). The final list of recipients were then determined based on the sub-village's quota. 